\title{
Blast Furnace Granulated Coal Injection System Demonstration Project: A DOE Assessment
}

June 2000

U. S. Department of Energy

National Energy Technology Laboratory

P.O. Box 880, 3610 Collins Ferry Road

Morgantown, WV 26507-0880

and

P.O. Box 10940, 626 Cochrans Mill Road

Pittsburgh, PA 15236-0940 


\section{Disclaimer}

This report was prepared as an account of work sponsored by an agency of the United States Government. Neither the United States Government nor any agency thereof, nor any of their employees, makes any warranty, express or implied, or assumes any legal liability or responsibility for the accuracy, completeness, or usefulness of any information, apparatus, product, or process disclosed, or represents that its use would not infringe privately owned rights. Reference therein to any specific commercial product, process, or service by trade name, trademark, manufacturer, or otherwise does not necessarily constitute or imply its endorsement, recommendation, or favoring by the United States Government or any agency thereof. The views and opinions of authors expressed therein do not necessarily state or reflect those of the United States Government or any agency thereof. 


\section{Contents}

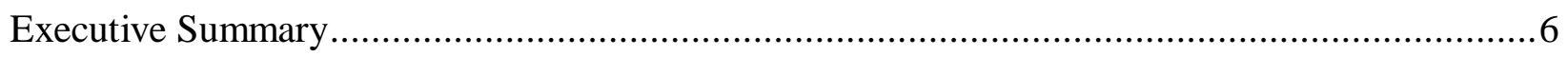

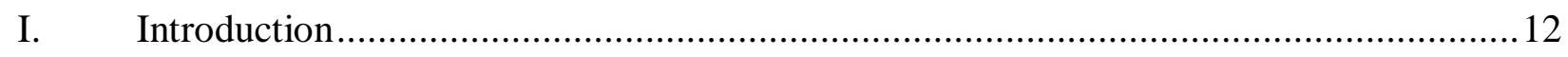

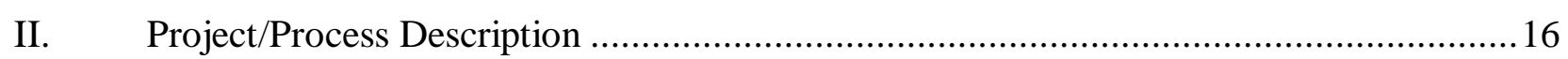

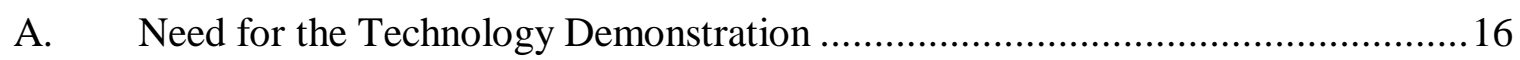

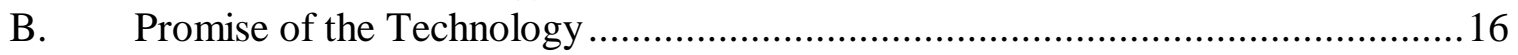

C. Project Description........................................................................................

D. Technology Description............................................................................. 17

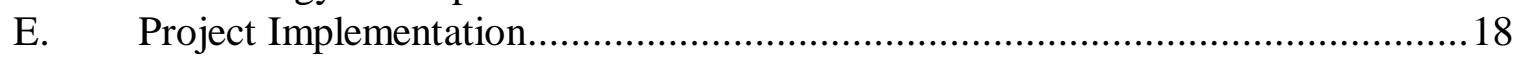

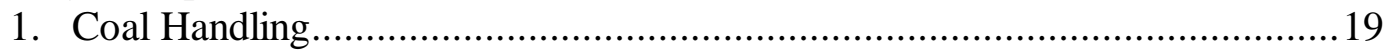

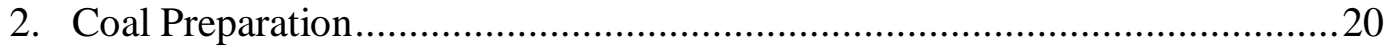

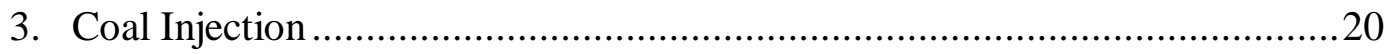

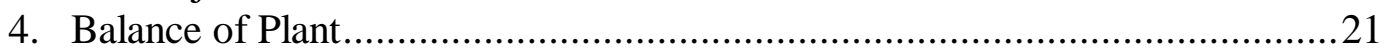

F. Project Objectives and Statement of Work ....................................................2

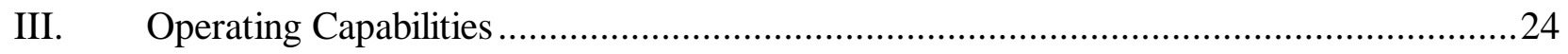

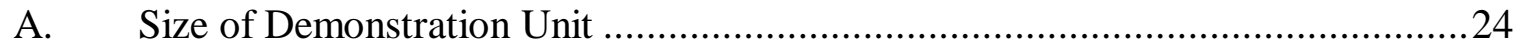

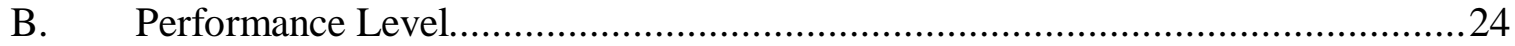

C. Major Operating and Design Variable Studied ................................................24

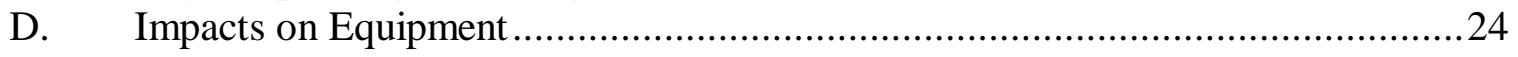

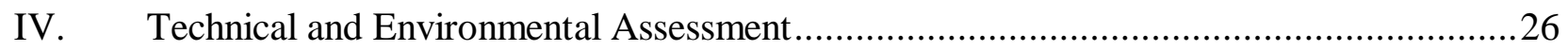

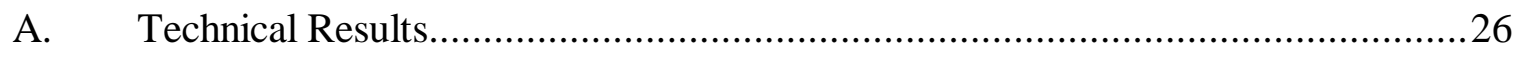

1. Granular Coal Injection Versus Natural Gas Injection ..................................22

2. High Ash Versus Low Ash Coal ..............................................................29

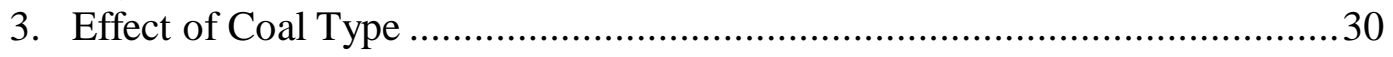

4. Granular Coal Versus Pulverized Coal .......................................................... 31

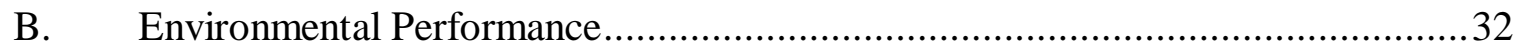

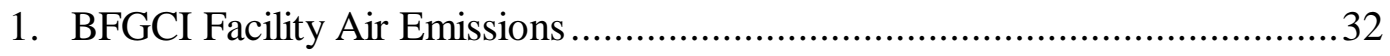

2. BFGCI Facility Wastewater Compliance ………….........................................33

3. CAAA Standards Applied to Cokemaking ………........................................33

C. Evaluation of Project Achievements...................................................................35

1. Design, Construct, and Operate BFGCI Demonstration Plant.........................35

2. Evaluate a Range of Coal Types and Particle Sizes .........................................36

3. Demonstrate Installation Without Prolonged Shutdown ..................................36

4. Demonstrate Scaleup of the BFGCI Technology .............................................36

5. Demonstrate Operation at Full Production Levels While Maintaining Hot Metal Quality..... .36 
6. Determine Blast Furnace Production Rate As a Function of the Feed Rates of the Various Furnace Inputs ...................................................36

7. Demonstrate Feasibility of Injecting Lower Quality Coal................................37

8. Characterize the Environmental Aspects of the BFGCI Demonstration...........37

9. Characterize the Process and By-Product Streams from the Demonstration...37

10. Provide Operating and Maintenance Data Suitable to Allow Technical and Economic Evaluation of the BFGCI Technology........................................37

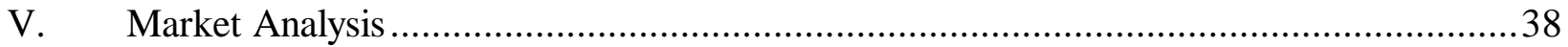

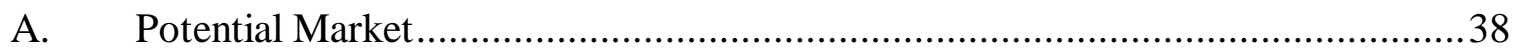

B. Economic Assessment …………...............................................................39

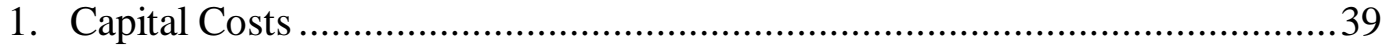

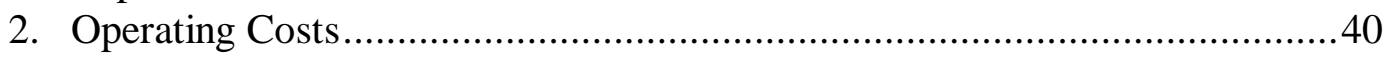

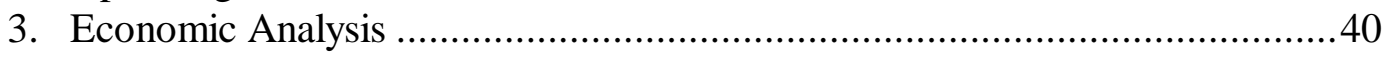

4. Comparison with Other Technologies ........................................................40

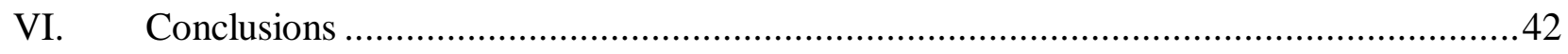

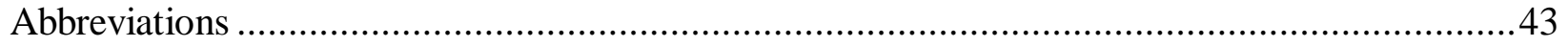

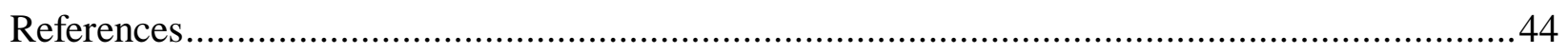

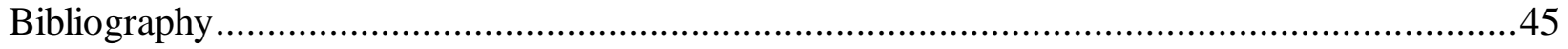




\section{List of Tables and Figures}

Table No.

Title

Page

1 Analyses of Coals Injected at Burns Harbor..................................................26

2 Comparison of Coal Injection with Natural Gas Injection ...................................2 27

3 Comparison of High and Low Ash Coals.......................................................29

4 Comparison of High and Low Volatile Coals....................................................... 31

$5 \quad$ List of Blast Furnaces in the U. S. ................................................................. 38

Figure No.

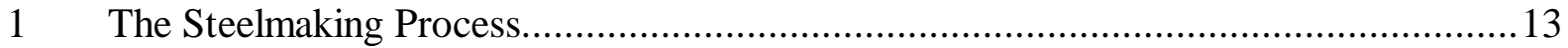

2 Typical Blast Furnace Complex ........................................................................ 14

3 Coal Preparation and Injection Facilities-Burns Harbor Plant ............................... 18

$4 \quad$ Application of Coal Injection.................................................................... 19

5 Regression Analysis_-Injected Coal vs. Adjusted Coke Rate ..................................28 


\section{Executive Summary}

This document is a U.S. Department of Energy (DOE) post-project assessment of a project funded in Round III of the Clean Coal Technology (CCT) program, the Blast Furnace Granulated Coal Injection System (BFGCI) Demonstration Project. In November 1990, Bethlehem Steel Corporation entered into an agreement with DOE to conduct this study and to jointly fund the project, with the project being sited at Bethlehem Steel's Burns Harbor, Indiana, plant on the shore of Lake Michigan. The BFGCI technology was developed jointly by British Steel and Simon-Macawber (now CPC-Macawber). DOE provided $16 \%$ of the total project funding of $\$ 194$ million. Construction for the demonstration project was started at the end of August 1993 and completed in January 1995, and the test program was initiated in November 1995 and completed in June 1999. This project was very successful and has yielded substantial economic and environmental benefits. Its operational success is validated by Bethlehem Steel's continued use of the equipment to inject granular coal into Blast Furnaces $\mathrm{C}$ and D on a permanent basis.

The BFGCI technology was demonstrated on a smaller scale (approximately half the capacity of the Burns Harbor furnaces) in England. The purpose of this CCT project was to demonstrate the BFGCI technology on a large blast furnace-greater than 5000 net tons of hot metal (NTHM) per day, and typical of furnaces in use throughout the world-utilizing a variety of U. S. coals. In addition, the purpose was to study the effect on furnace performance of the particle size of the injected coal and to determine the maximum coke replacement level.

One of the major thrusts of the CCT program is to demonstrate technologies that can enable the industrial use of coal in an economic and environmentally safe manner. The BFGCI process is particularly well suited to improving blast furnace economics by replacing coke with coal, thus reducing coke requirements, while at the same time reducing pollution by decreasing coke production. Cokemaking is the major source of pollution in the production of raw iron.

Airborne pollution from the blast furnace itself is minimal due to the chemistry in the blast furnace and installation of pollution control equipment. In the blast furnace, sulfur in the coal is removed by reaction with the limestone added to the furnace and ends up in the slag. The blast furnace is a closed vessel, and the gas leaving the furnace is cleaned of particulates and other contaminants by existing cyclones and wet scrubbers before being burned as fuel. Therefore, injecting coal does not result in any increase in pollution from the blast furnace. The BFGCI technology uses direct injection of coal into the blast furnace to replace some (up to about one third) of the coke.

When originally put into service, the Burns Harbor Plant could produce all the coke required for the two blast furnaces operating at 5,000 NTHM per day each (10,000 NTHM per day total). However, improved practices and raw materials have resulted in blast furnace operations that now can produce a total of over 14,000 NTHM per day, a $40 \%$ increase. Since the coke oven batteries are not able to produce the coke required for this level of blast furnace output, other sources of coke and energy are required, such as injecting auxiliary fuels into the blast furnaces. The most successful auxiliary fuel through the 1980s and early 1990s was natural gas. It is easy to inject and, at moderate injection levels, has a highly beneficial effect on blast furnace operations 
and performance. However, the amount of natural gas that can be injected is limited due to its greater cooling effect because of its high hydrogen content, and prices on a unit energy content basis tend to be higher than for coal.

A major reason for evaluating granular coal injection on U. S. blast furnaces is the fact that U. S. cokemaking facilities are rapidly aging. A high capital investment will be required to rebuild these facilities to meet emissions requirements under the Clean Air Act Amendments (CAAA) of 1990. Increasingly stringent environmental regulations and the continuing decline in domestic cokemaking capability over the coming years will cause significant reductions in the availability of coke along with coke price increases. Blast furnace injection of coal will allow domestic integrated steel producers to maintain production while minimizing their dependence on coke.

The BFGCI process uses granular coal, which is cheaper to produce than the pulverized coal required by many other blast furnace coal injection technologies. The BFGCI technology has characteristics that make it very attractive for application in the U. S. basic steel industry:

- Potential cost savings due to lower capital and operating costs for granular coal compared to pulverized coal.

- Easier handling of granular coal in pneumatic conveying systems.

- High coke replacement ratios.

- High system availability.

- Unique variable speed.

- Positive displacement injectors.

Installation of BFGCI technology at Burns Harbor required adding new equipment in four areas: raw coal handling, coal preparation, coal injection, and balance of plant. The raw coal handling facilities include the coal storage area, mobile reclaim equipment, conveyor, screen, and dust control. The coal preparation facilities include conveyors, surge bins, coal granulator/pulverizer mills, coal dryers, particle separators, dust filters, and screens. The coal injection facilities include coal storage silos, weigh bins, distribution bins, coal injectors, and coal injection lances. The balance of plant includes plant utilities, process measurement and control, and electrical.

One of the objectives of this project was to determine the range of properties of the injected coal, which would result in satisfactory blast furnace performance. To achieve this objective, coal type, composition, and particle size were varied, and the following performance comparisons were made: (1) operation with granular coal injection compared to operation with natural gas injection; (2) high ash bituminous coal injection compared to low ash bituminous coal injection; (3) effect of coal type (high volatile bituminous coal injection compared to low volatile bituminous coal injection); and (4) granular coal injection compared to pulverized coal injection Four test coals were defined as follows:

Test Coal A -- An Eastern bituminous coal having a low ash content (less than $6.5 \%$ ), a low sulfur content (less than 1\%), and an inherent moisture content of less than $2.5 \%$ (low volatility Buchanan coal). 
Test Coal B -- An Eastern bituminous coal having a moderate ash content (greater than $7 \%$ ), a higher sulfur content (greater than $1 \%$ ), and an inherent moisture content of less than $2.5 \%$ (high-ash Buchanan coal, produced by eliminating one of the cleaning steps).

Test Coal C -- Granulated high volatile Western bituminous coal (Oxbow coal).

Test Coal D -- Pulverized high volatile Western bituminous coal for comparison with granulated Test Coal C (Oxbow coal).

The most significant difference in operations injecting granular coal compared with operations injecting natural gas was a decrease in wind volume with coal injection, which resulted from increased oxygen enrichment and moisture addition in the form of steam. These changes were necessary to achieve satisfactory permeability and burden movement. Furnace slag chemistry also changed, with sulfur content increasing somewhat with coal injection; slag volume also increased.

Although operating conditions had to be altered somewhat, operation with injected granular coal was quite satisfactory and presented no major problems. The quantity of blast furnace coke that is replaced by an injected fuel is an important aspect of the overall value of the injectant. Operating data were used in a regression analysis to determine the replacement ratio of granulated coal injection. The slope of the best fit line is 0.96 , that is, 0.96 fewer pounds of coke are required for each pound of granular coal injected. This is an excellent replacement rate, significantly better than the 0.8-0.9 replacement ratio reported for other coal injection projects.

To eliminate coal composition as a variable in the test of high ash versus low ash coal, one of the steps in the coal cleaning process used at the Buchanan mine was skipped. This increased the ash content of the coal by 2.4-3.0\% without significantly changing the analysis on an ash free basis. Operations with the higher ash coal were compared with a similar period injecting lower ash coal. The operating periods being compared had similar wind rates, blast pressure, top pressure, oxygen enrichment, and moisture addition. The major conclusions from this test were that:

- Furnace permeability was not adversely affected by the higher ash coal.

- Blast pressure and wind volume could be maintained at the same conditions as for low ash coal.

- Hot metal silicon and sulfur contents and variability were comparable to operations with low ash coal.

However, as expected, slag volume increased 3-8\% compared to low ash coal operations. For each $1 \%$ increase in coal ash content, there is about a $3 \mathrm{lb} / \mathrm{NTHM}$ increase in the coke requirement.

The test between high volatile and low volatile coals was made comparing low volatile Eastern bituminous coal (Buchanan) and high volatile Western bituminous coal (Oxbow). Although furnace operation was satisfactory with the Oxbow coal from Colorado, the coke rate was higher than for operation with low volatile bituminous coal. Part of this difference can be attributed to the lower carbon content of the Oxbow coal, and the rest is due to the higher ash content of the Oxbow coal, which results in a larger slag volume. 
The coal used for the study comparing granular coal with pulverized coal was made with high volatile Oxbow coal. The pulverized coal injection rate was somewhat lower than that for granular coal because of the limited capacity of the grinding mills to produce pulverized coal. Comparison of furnace performance for the two coal sizes shows very similar results, indicating that there is no advantage of further reducing particle size below granular range. In fact, there is an economic disadvantage associated with pulverized coal, as both the capital and operating costs are higher.

Because costs tend to be very site specific, it is difficult to provide costs that are generally applicable to a wide number of blast furnaces. The installed capital cost for the equipment needed to operate the BFGCI technology on one blast furnace at Burns Harbor was \$15.1 million in 1990. These are the costs for one injection facility. At Burns Harbor, two units were installed, one for Furnace C and one for Furnace D. The \$15.1 million figure does not include the cost of site preparation, buildings, utilities, and other infrastructure modifications. At Burns Harbor, these facilities required an additional $\$ 87$ million, although infrastructure costs are quite site specific and can vary widely from location to location. Each of these facilities has the capability to inject up to 1440 tons of granular coal per day. On this basis, capital costs are in the neighborhood of \$35-40 thousand per daily ton of coal injected.

As with capital costs, operating costs are also highly site specific. In particular, they will depend upon coal cost, labor rates, and utility costs. At Burns Harbor in June 1999, operating costs (excluding capital charges) were about $\$ 10 /$ ton of injected coal. To this must be added the cost of coal, which runs \$50-60/ton for the low volatile coal delivered to Burns Harbor from Virginia. Thus, total operating costs are in the range of $\$ 60-70 /$ ton of injected coal, not including capital charges. An analysis of Burns Harbor operations indicates a net savings in fuel costs from injecting granular coal of $\$ 6.50 /$ NTHM.

Each of the two blast furnaces averages about $7000 \mathrm{NTHM} /$ day, for a yearly production rate of 5.11 million tons. The total capital investment for the BFGCI system, including cost of equipment and infrastructure improvements, was $\$ 117$ million. This gives a payout period of 3.4 years. This is a very attractive payout period and shows that the BFGCI technology can significantly improve the economics of blast furnace operation.

It is difficult to compare the economics of the BFGCI system with other blast furnace coal injection technologies. In general, information on other technologies is not available due to the proprietary nature of the data required for a satisfactory comparison. However, a few general comments are possible. Because of the short payout period, the BFGCI system should compare favorably with other coal injection technologies. In particular, since BFGCI uses granular coal versus pulverized coal used by some other systems, the savings in grinding costs should lead to superior economics for the BFGCI technology.

The primary responsibility for commercialization of the BFGCI technology lies with ATSI, Inc., the subcontractor for the granular equipment for the demonstration project. Bethlehem Steel's responsibility has included making the demonstration project available for observation, providing operating and engineering personnel for discussion with potential customers, providing test data 
on the coals and process variables tested and participation in the preparation and presentation of technical papers pertaining to the demonstration program. Successful completion of the demonstration project provides an important marketing factor in promoting granular coal injection. Replication of the technology will fulfil a major goal of the CCT program, that of increasing the industrial use of coal in a cost-effective and environmentally friendly manner.

A market study indicates that, of the 35 blast furnaces currently operating in the United States, 17 already use some form of coal injection. These are probably not immediate candidates for the BFGCI process, although the cost savings in moving from pulverized to granular coal may provide an incentive for some of these furnaces to switch to BFGCI technology. The other 18 blast furnaces are candidates for installation of the BFGCI technology.

The BFGCI Demonstration Project, which represents the first demonstration of granular coal injection into a blast furnace in the U.S., was highly successful. The required equipment was designed, installed, and started up with a minimum of problems. The technology performed as expected, and a series of tests was successfully carried out. The economics have proven to be quite favorable, and Bethlehem Steel is continuing to use the BFGCI system on a commercial basis. Environmentally, this technology reduces emissions from coke production by decreasing blast furnace coke requirements on essentially a pound for pound basis, that is, for every pound of coal injected one less pound of coke is required.

Specific conclusions derived from this demonstration project are:

- Granular coal injection on a large, modern blast furnace is technically sound and economically viable. Coal can replace coke on an almost pound for pound basis.

- There is no need to pulverize the coal, since granular coal performs as well as pulverized coal.

- There is a significant economic advantage to using granular coal over pulverized coal, since not only is less grinding equipment required with consequent capital cost savings, but operating costs are also reduced as approximately $60 \%$ less grinding energy is required for granular coal.

- Although both high volatile and low volatile coals can be injected, blast furnace operation with granular low volatile coal is superior to operation with granular high volatile coal. A pound of low volatile coal replaces more coke than a pound of high volatile coal.

- With certain coals, such as low volatile coal, it is necessary to use granular sizing, because line plugging and other problems arise when trying to inject these as pulverized coals. Thus, the use of granular coal may increase the range of coals available for blast furnace injection.

- Although higher ash coals can be successfully injected, at an injection rate of $260 \mathrm{lb} / \mathrm{NTHM}$, there is a coke rate disadvantage of about $3 \mathrm{lb} / \mathrm{NTHM}$ for each percent increase in the ash content of the injected coal. However, the higher ash content has no adverse effect on furnace permeability, productivity, or hot metal quality. 
- Since cokemaking is the major source of pollution from steelmaking, the use of coal injection to reduce coke requirements significantly reduces emissions from the steelmaking process. 


\section{Introduction}

The goal of the U.S. Department of Energy's (DOE) Clean Coal Technology (CCT) program is to furnish the energy marketplace with a number of advanced, more efficient, and environmentally responsible coal utilization technologies through demonstration projects. These projects seek to establish the commercial feasibility of the most promising advanced coal technologies that have developed beyond the proof-of-concept stage.

This document serves as a DOE post-project assessment of a project selected in CCT Round III, the Blast Furnace Granulated Coal Injection System Demonstration Project, as described in a Report to Congress [U.S. Department of Energy, 1990]. In November 1990, Bethlehem Steel Corporation entered into a cooperative agreement with DOE to conduct the study. The project was sited at Bethlehem Steel's Burns Harbor Plant, in Burns Harbor, Indiana, located on the southern shore of Lake Michigan, about 30 miles east of Chicago. The Blast Furnace Granulated Coal Injection (BFGCI) technology was developed jointly by British Steel and Simon-Macawber (now CPC-Macawber). The technology was demonstrated on a smaller scale (approximately half the capacity of the Burns Harbor furnaces) in England. The purpose of this CCT project was to demonstrate the BFGCI technology on a world-scale sized blast furnace utilizing U. S. coals. DOE provided $16 \%$ of the total project funding of $\$ 194$ million.

Construction for the demonstration project was started at the end of August 1993 and completed in January 1995, and the test program was initiated in November 1995 and completed in November 1998. The independent evaluation contained herein is based primarily on information from Bethlehem Steel's Final Report Volume 2, dated October 1999, as well as other references cited.

One of the major objectives of the CCT Program is to develop technologies that reduce emissions from industrial applications that use coal as a fuel or reactant. Conventional ironmaking requires the use of coke, made from coal, to provide permeability in the blast furnace (i.e., to allow satisfactory flow of hot gases up through the furnace and movement of solids down through the furnace) and as a source of the reducing gas, primarily carbon monoxide (CO) with some hydrogen $\left(\mathrm{H}_{2}\right)$, that converts iron ore to molten iron. Coke is prepared from coal by a pyrolysis process that can generate significant amounts of pollutants, including emissions of airborne and waterborne toxic impurities along with nitrogen- and sulfur-containing contaminants. The BFGCI technology uses direct injection of coal into the blast furnace to replace some (up to about onethird) of the coke. Since cokemaking is the major source of pollution in the production of raw iron, the BFGCI process achieves a significant reduction in emissions resulting from steelmaking.

Airborne pollution from the blast furnace itself is minimal. In the blast furnace, sulfur in the coal is removed by reaction with the limestone added to the furnace and ends up in the slag. The blast furnace is a closed vessel, and the gas leaving the furnace is cleaned by existing cyclones and wet scrubbers before being burned as fuel. Therefore, injecting coal does not result in any increase in pollution from the blast furnace. Thus, in addition to improved economics, the major benefit from application of the BFGCI process is the significant reduction of pollutants from cokemaking due to decreased blast furnace coke requirements. 
The project site is immediately adjacent to the Indiana Dunes National Lakeshore, an area that is particularly sensitive from an environmental standpoint. Therefore, environmental performance at the plant is an important aspect of the project. Figure 1 shows how blast furnace operations fit into the overall steelmaking scheme.

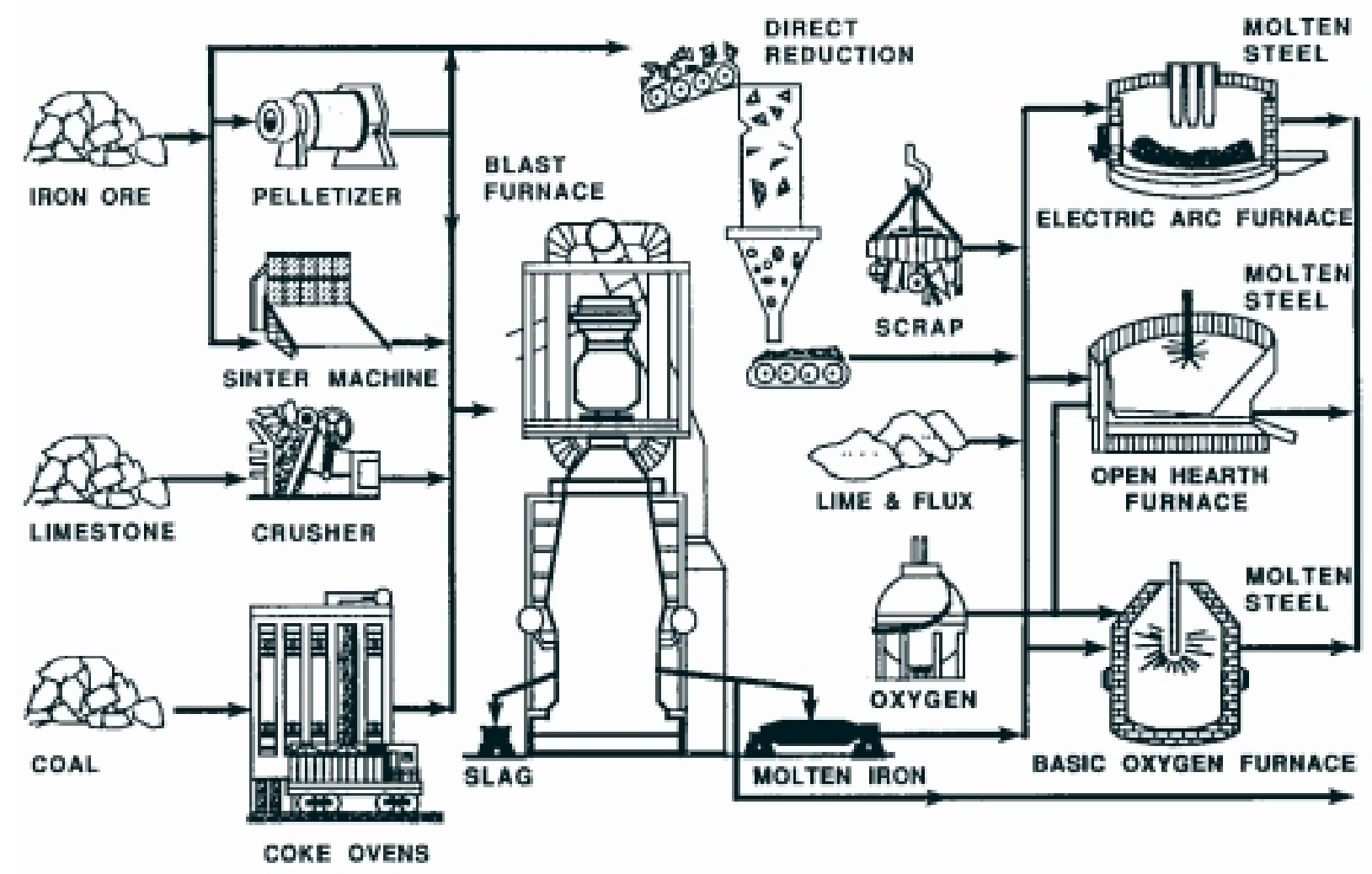

Figure 1: The Steelmaking Process 
Figure 2 is a schematic of typical blast furnace operations.

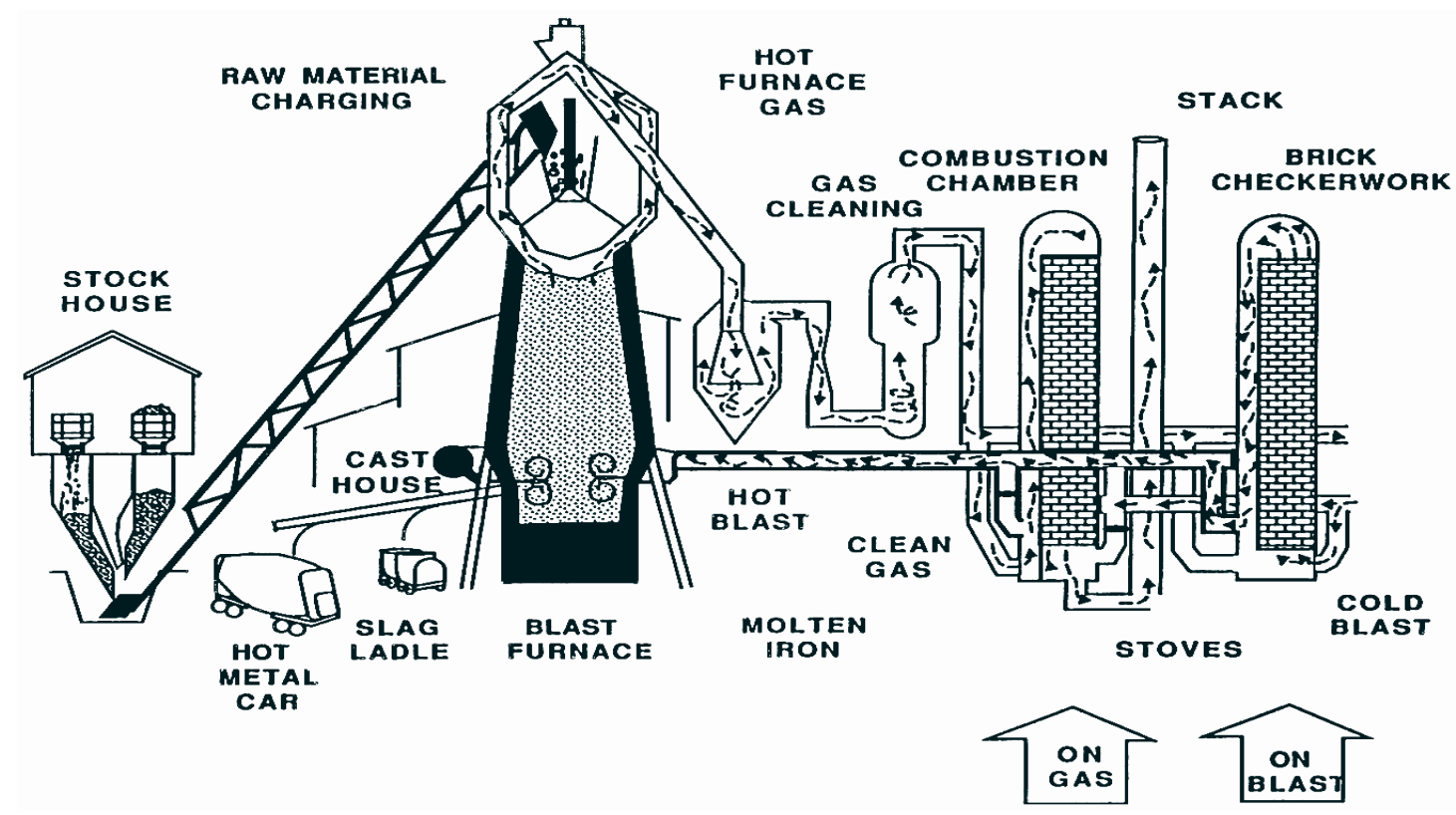

Figure 2: Typical Blast Furnace Complex

The Burns Harbor Plant is an integrated operation that includes two coke oven batteries, an iron ore sintering plant, two blast furnaces, a three-vessel basic oxygen furnace (BOF) shop, and two twin-strand slab casting machines. These primary facilities can produce over five million tons of raw steel per year. The steel finishing facilities at Burns Harbor include a hot strip mill, two plate mills, a cold tandem mill complex, and a hot dip coating line. The BFGCI technology is installed on both Blast Furnaces $C$ and D. Each of these units has a production capacity of 7,000 net tons of hot metal (NTHM) per day.

When originally put into service, the Burns Harbor Plant could produce all the coke required for the two blast furnaces operating at 5,000 NTHM per day each (10,000 NTHM per day total). However, improved practices and raw materials have resulted in blast furnace operations that now can produce a total of over 14,000 NTHM per day. Since the coke oven batteries are not able to produce the coke required for this level of blast furnace output, other sources of coke and energy have been used to fill the gap. Over the years, coke has been shipped to Burns Harbor from other Bethlehem plants and from outside coke suppliers. In addition, auxiliary fuels, such as coal tar, fuel oil, and natural gas, have been injected into the blast furnaces to reduce the coke requirements. The most successful auxiliary fuel through the 1980s and early 1990s was natural gas. It is easy to inject and, at moderate injection levels, has a highly beneficial effect on blast 
furnace operations and performance. However, the amount of natural gas that can be injected is limited, and prices on a unit energy content basis are typically higher than for coal.

In 1994, the C furnace was relined. During this reline, the C furnace was enlarged slightly, and the refractory cooling system was upgraded to a high-density plate-cooling configuration. The furnace stack region on $\mathrm{C}$ has closely spaced cooling plates that are not on the $\mathrm{D}$ furnace. This high-density cooling was specifically designed for the rigors of high coal injection rates and to provide for increased production capacity. Because of these improvements, it was decided to use the $\mathrm{C}$ furnace as the primary unit for the granular coal injection tests. However, because of some problems with $\mathrm{C}$ furnace, some of the tests were performed on the $\mathrm{D}$ furnace. 


\section{Project/Process Description}

This section discusses the technology being demonstrated and the project that was set up to carry out the demonstration.

\section{II.A. Need for the Technology Demonstration}

A major reason for evaluating granular coal injection on U. S. blast furnaces is the fact that U. S. cokemaking facilities are rapidly aging. A high capital investment would be required to rebuild these facilities to meet emissions requirements under the Clean Air Act Amendments (CAAA) of 1990. Increasingly stringent environmental regulations and the continuing decline in domestic cokemaking capability will cause significant reductions in the availability of coke over the coming years. Between 1990 and 1995, coke production in the U. S. declined almost 4 million tons per year. Due to this decline in availability and the increase in operating and maintenance costs for domestic cokemaking facilities, coke prices are projected to increase by more than general inflation. Blast furnace injection of coal will allow domestic integrated steel producers to maintain production while minimizing their dependence on coke.

\section{II.B. Promise of the Technology}

Direct coal injection into blast furnaces offers the promise of significantly improved steelmaking operations. Since coke is produced from coal, to the extent that blast furnace coke can be replaced by coal, the coke processing step for that coal is eliminated, and the pollution associated with that coke production is also eliminated. Thus, direct coal injection results in both improved economics and reduced pollution.

The BFGCI process, in particular, offers the promise of improved economics, because it uses granular coal, which is cheaper to produce and easier to handle than the pulverized coal required by many other blast furnace coal injection technologies. Although coal properties affect economics and the coke replacement rate, almost any coal can be used provided the process equipment is properly designed to handle it. However, as discussed later, coals with certain properties, such as high grindability index, low sulfur, and low ash, are preferred.

Another promise of the technology is to significantly reduce pollution from cokemaking, due to the reduced amount of coke required to produce a ton of steel. Since blast furnace operations are generally less polluting than cokemaking, the environment benefits when coal is directly injected into the blast furnace, instead of first being coked. Furthermore, this is accomplished without increasing pollution from the blast furnace or otherwise upsetting blast furnace operations. Some modifications to operations may be required, such as altering slag composition, increasing oxygen enrichment of the hot blast, and adding steam to the hot blast, but these are easily accomplished. Hot metal chemistry is not significantly affected by granular coal injection. 


\section{II.C. Project Description}

As discussed previously, improvements to operations at Burns Harbor that increased blast furnace capacity also increased the coke requirements beyond what the existing coke plants could produce. In order to offset the need for additional coke, supplemental fuels were injected into the blast furnaces. Prior to initiating the BFGCI Project, natural gas was injected into the blast furnaces at Bethlehem Steel's Burns Harbor Plant as a fuel supplement to decrease coke requirements. However, two significant problems with the use of natural gas are high cost and a limitation on the amount that can be injected, which limits the reduction in coke usage.

The combustion of "cold" fuel injected into the lower part of a blast furnace produces reducing gases with a lower heat content than the gases produced by burning coke that has been heated to a high temperature. Also, when the injected fuel has a high hydrogen-to-carbon (H/C) ratio, less heat is evolved in the combustion of that fuel to $\mathrm{CO}$ and $\mathrm{H}_{2}$. Natural gas has a high $\mathrm{H} / \mathrm{C}$ ratio and, therefore, has a larger cooling effect. The selection of coal in preference to other injectant fuels is based on the fact that the endothermic effect of coal on the high temperature heat supply to the lower furnace is the smallest of all potential injected fuels. Preliminary studies at Burns Harbor had indicated that coal injection would permit a larger reduction in coke usage than that achieved with natural gas (from about a $20 \%$ reduction with natural gas to about a $30 \%$ reduction with coal) and would lower the cost of iron production.

The prospect of higher coke replacement levels with coal injection led Bethlehem to submit a CCT proposal to DOE to conduct a comprehensive assessment of coal injection on the Burns Harbor blast furnaces. This proposal was accepted in 1989 as one of the CCT Round III projects, and a cooperative agreement was signed in November 1990. Construction started in August 1993 and was completed in January 1995. The major objectives of the test program, which began in November 1995 and was completed in December 1998, were to evaluate the effect of coal injection on the operation of large (greater than $5000 \mathrm{NTHM} /$ day) blast furnaces, study the effect of the particle size of the injected coal on furnace performance, determine the maximum coke replacement level, and try a variety of U. S. coals.

\section{II.D. Technology Description}

An important factor relative to coal injection into a blast furnace is the particle size of the injected coal. Two coal sizes are commonly used: (1) finely powdered coal, referred to in this report as pulverized coal and defined as $70-80 \%$ passing through a 200 -mesh screen; and (2) a less finely ground coal, referred to as granular coal and defined as only $10-30 \%$ of the particles passing through a 200-mesh screen. Pulverized coal is similar in particle size to face powder, while granular coal is similar to granulated sugar. Bethlehem decided to use the BFGCI system because, unlike more widely used systems that can inject only pulverized coal, the BFGCI system is also capable of injecting granular coal. Thus, one of the objectives of the CCT project at Burns Harbor was to compare injection of pulverized coal with that of granular coal. 
The BFGCI technology has characteristics that make it very attractive for application in the U. S. basic steel industry:

- Potential cost savings, because the capital and operating costs for a granular coal preparation system are significantly less than those for the same capacity pulverized coal preparation system.

- Granular coal is easier to handle in pneumatic conveying systems since granular coal is not as likely to stick to conveying pipes.

- Coke replacement ratios (defined as the decrease in the pounds of coke required per pound of coal injected) obtained by British Steel using BFGCI are as high or higher than those achieved by other systems.

- High system availability, which has exceeded 99\% during several years of operation at British Steel.

- Unique variable speed, positive displacement injectors provide superior flow control and measurement compared to other coal injection systems.

\section{II.E. Project Implementation}

Installation of BFGCI technology at Burns Harbor required adding new equipment in four categories: raw coal handling, coal preparation, coal injection, and balance of plant. Figure 3 is a schematic of the BFGCI technology installed on a blast furnace, and Figure 4 illustrates how the technology integrates into overall blast furnace operations.

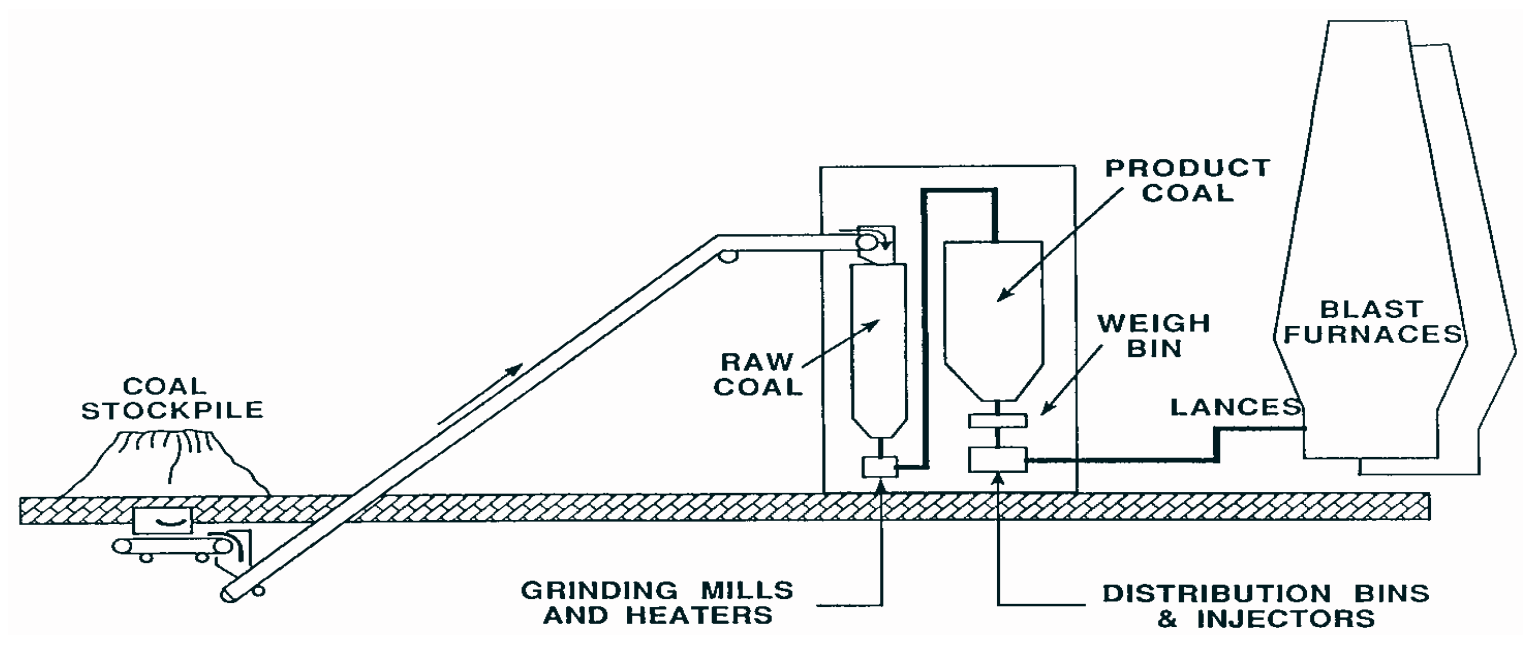

Figure 3: Coal Preparation and Injection Facilities, Burns Harbor Plant 


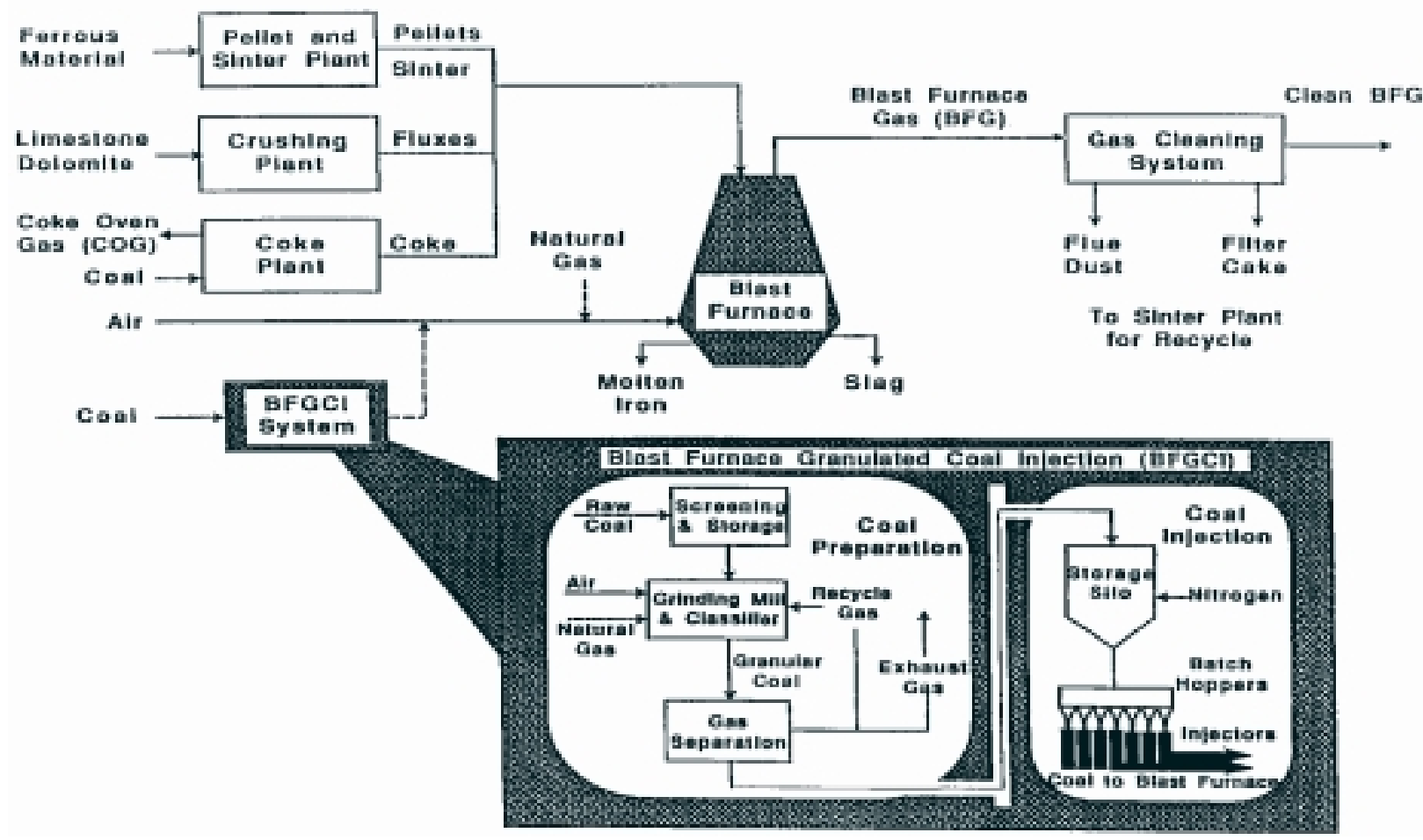

Figure 4: Application of Coal Injection

\section{II.E.1. Coal Handling}

The raw coal handling system includes the coal storage area, mobile reclaim, conveyor, screen, dust control, fire protection, and buildings and structures for the coal handling components.

Coal for use as blast furnace injection fuel is received at the existing facilities, which are used to handle coal sent to the coke ovens. The coal is unloaded using the existing railroad car dumper, which is part of the blast furnace material handling system. The existing conveyor was modified to enable the coal to be sent either to the coke ovens or to a pile used to store the coal destined for blast furnace injection. The coal pile has 10-days' storage capacity (approximately 28,000 tons). The material handling system, which moves the coal from the car dumper to the storage pile, is sized at 2,300 tons per hour, which matches the output of the car dumper.

Four coal reclaim hoppers are located in a tunnel, constructed beneath the coal storage area. These hoppers feed a conveyor which transports coal at a rate of $400 \mathrm{tons} / \mathrm{hr}$ to the south end of the storage pile and discharges the coal onto a vibrating screen to separate coal over two inches in size from the main stream of particles less than two inches. The oversized coal passes through a precrusher to reduce its size to less than two inches and is then mixed with the rest of the coal and conveyed to the top of the building that houses the coal preparation facilities. 


\section{II.E.2. Coal Preparation}

The coal preparation system includes conveyors, surge bins, coal granulator/pulverizer mills, coal dryers, particle separators, dust filters, screens, fire protection, and buildings and structures for the coal preparation system components.

The coal preparation facility is housed in a building constructed as part of this project. It contains two cylindrical steel raw coal storage silos with conical bottoms. These silos are entirely enclosed and have a vent filter on top to prevent escape of coal dust. Each silo holds 240 tons of coal, which is a four-hour supply at the maximum injection rate. Air cannons are installed in the conical section to loosen the coal and ensure that flow is maintained through the silo.

Coal from the silos flows into a feeder which controls the coal rate to the preparation mills. There are two grinding mills, each capable of producing 30 tons per hour of pulverized coal or 60 tons per hour of granular coal, thus permitting testing of both particle size ranges of coal. The lower capacity of the mills when producing pulverized coal means that pulverized coal injection could not be tested at the maximum rate achieved for granular coal injection. This illustrates the cost benefit for operating with granular coal, since more mills would be required to inject pulverized coal.

In the mills, coal is ground to the desired particle size. Flue gas, generated in a natural-gas-fired burner, is mixed with recycled gas from the downstream side of the process and swept through the mills' grinding chambers. The hot gas lifts the ground coal from the mills vertically through classifiers where oversized particles are circulated back to the mills. Properly sized coal is transported from the mills in 52-inch ducts. Coal particles are separated from the gas by cyclones. During transport, the coal is dried to $1-1.5 \%$ moisture. The oxygen content of the drying gas is controlled to stay below the combustion limit.

The dried coal is screened to remove any remaining oversized material and then sent by screw conveyors to one of four 180-ton storage silos. From the storage silos, a weigh hopper dumps twoton batches into the distribution bins that are part of the coal injection facility.

\section{II.E.3. Coal Injection}

The coal injection system includes coal storage silos, weigh bins, distribution bins, coal injectors, coal injection lances, and buildings and structures for the coal injection system components.

Because of the capacities of the blast furnaces, supplying the requisite amount of coal requires two parallel sets of coal injection equipment for each furnace. Each set of equipment consists of one product coal silo, one weigh hopper, one distribution bin, and 14 injector systems. Thus, the coal injection facility includes a total of four distribution bins (two for each furnace located under the weigh hoppers for that furnace). 
At the bottom of each distribution bin are 14 conical pant legs. Each pant leg feeds an injector, which allows a small amount of coal to pass continually to an injection line. In the injection line, the coal is mixed with high-pressure air and carried approximately 600 feet to one of the 28 injection lances, one on each of the 28 tuyeres on each furnace. At the injection lance tip, the coal is mixed with the hot blast and carried into the furnace raceway. The 14 injectors at the bottom of each of the two distribution bins associated with a particular furnace feed alternate furnace tuyeres.

\section{II.E.4. Balance of Plant}

The balance of plant system includes, but is not limited to, the plant utilities, process measurement and control, and electrical.

\section{II.F. Project Objectives and Statement of Work}

The general objective of this project as listed in the cooperative agreement awarded on November 26,1990 , was to demonstrate the technical and economic viability of injecting granulated or pulverized coal as a fuel supplement into the Bethlehem Steel Corporation's Burns Harbor Blast Furnaces $\mathrm{C}$ and $\mathrm{D}$. An initial target of reaching a maximum coal injection rate of $400 \mathrm{lb}$. per NTHM was set. Specific objectives, as listed in the cooperative agreement, were to:

- Engineer, design, construct, operate, and manage the BFGCI Demonstration Plant.

- Evaluate coal injection over a broad range of coal particle sizes while using coals with a wide range of properties, such as Eastern and Midwestern bituminous and Western subbituminous.

- Demonstrate the feasibility of installing the coal injection system on one furnace out of service for relining and on a second furnace during brief outages.

- Demonstrate the feasibility of scale-up by injecting granular coal into large, high-production blast furnaces producing more than 5,000 NTHM/day.

- Demonstrate operation at hot metal production levels up to the current Burns Harbor maximum of $7500 \mathrm{NTHM}$ /day/furnace while maintaining hot metal quality.

- Determine the NTHM/day plant production rate from the blast furnaces as a function of coal, coke, flux, sinter and pellets, air, and oxygen.

- Demonstrate feasibility of injecting lower quality coals with lower replacement ratios.

- Characterize the environmental aspects of the operating BFGCI Demonstration Plant.

- Characterize the various by-products and process streams of the BFGCI Demonstration Plant. 
- Provide the operational and maintenance data suitable for the technical and economic evaluation of the technology for this and other commercial-scale BFGCI plants.

The project was divided into three phases, as follows:

- Phase I -- Design and Permitting

- Phase II -- Construction and Startup

- Phase III -- Operation and Data Collection

Phases I and II are self explanatory and were completed satisfactorily. The stated objective of Phase III was to operate the BFGCI Demonstration Plant on a variety of U. S. coals and to report on plant operations. The testing could be done on either the $\mathrm{C}$ or D Blast Furnace, but the data from the other furnace was to be compared to the data from the furnace on which the test was performed. Tests were to be run on four coals defined as follows:

Test Coal A -- An Eastern bituminous coal having a low ash content (less than 6.5\%), a low sulfur content (less than 1\%), and an inherent moisture content of less than $2.5 \%$.

Test Coal B -- An Eastern bituminous coal having a moderate ash content (greater than $7 \%$ ), a higher sulfur content (greater than 1\%), and an inherent moisture content of less than $2.5 \%$.

Test Coal C -- A Midwestern bituminous coal having a low ash content (less than 6\%), a moderate-to-high sulfur content (about 1\%), and a higher inherent moisture content (between $5 \%$ and $10 \%$ ).

Test Coal D -- A Western subbituminous coal having a low ash content (less than 5\%), a low sulfur content (less than 0.5\%), and a high inherent moisture content (greater than 15\%).

During the course of the project, there were several modifications to the cooperative agreement. Most of these dealt with minor items, such as no-cost time extensions. However, one modification changed the definition of the test coals. Test Coal $\mathrm{C}$ was to be a Midwestern bituminous coal with less than $10 \%$ moisture content. After a search, Bethlehem Steel was unable to find a Midwestern bituminous coal with a composition consistent with blast furnace requirements and that was being produced in sufficient quantity to allow a test. DOE attempted to assist in locating a suitable Midwestern coal, but was unsuccessful. Other experience in the steel industry indicated that problems were experienced with injecting Illinois coal into blast furnaces, and Bethlehem Steel personnel decided that it was not in their best interest to put their blast furnaces at risk.

Since the BFGCI Demonstration Plant was not designed to handle a coal moisture content of greater than $10 \%$, it was not feasible to operate with a higher moisture Midwestern coal. Similarly, a high moisture subbituminous coal could have been difficult to process. Therefore, it was decided to redefine Test Coals $\mathrm{C}$ and $\mathrm{D}$ as follows:

Test Coal C -- Granulated high volatile Western bituminous coal. 
Test Coal D -- Pulverized high volatile Western bituminous coal for comparison with granulated Test Coal C.

When the tests were performed, Test Coal A was low volatility Buchanan coal; Test Coal B was high-ash Buchanan coal, produced by eliminating one of the cleaning steps; Test Coal C was granulated high-volatile Oxbow coal from Colorado; and Test Coal D was pulverized Oxbow coal. 


\section{Operating Capabilities}

This section discusses the operating capabilities demonstrated in this project, including the size of the unit, performance levels, and variable studied.

\section{III.A. Size of Demonstration Unit}

The Burns Harbor plant has two blast furnaces, Furnaces C and D, and the BFGCI technology is installed on both furnaces. Each of these units has a production capacity of 7,000 NTHM/day. Successful demonstration of the BFGCI technology at this scale ensures that it can be installed on virtually any furnace world wide, since scale-up from the demonstrated size to the size of the largest existing furnaces is easily feasible.

\section{III.B. Performance Level}

The most important parameter in assessing the performance of the BFGCI technology is the reduction in the coke usage per pound of injected coal that can be achieved without suffering any adverse effects on unit operations. A variety of conditions were investigated in this project. The best results were obtained with granulated low-volatile, low-ash bituminous coal. With this coal, injection levels as high as $295 \mathrm{lb} / \mathrm{NTHM}$ were achieved with no loss in furnace performance or hot metal quality. With this coal, the coke replacement ratio was nearly one pound of coke per pound of injected coal, an excellent replacement ratio.

\section{III.C. Major Operating and Design Variables Studied}

One of the objectives of this project was to determine the range of properties of the injected coal that would result in satisfactory blast furnace performance. To achieve this objective, coal type, composition, and particle size were varied, and the following performance comparisons (results from these test are discussed in detail in Section IV.A.) were made:

- Operation with granular coal injection compared to operation with natural gas injection

- High volatile bituminous coal injection compared to low volatile bituminous coal injection

- High ash bituminous coal injection compared to low ash bituminous coal injection

- Granular coal injection compared to pulverized coal injection 


\section{III.D. Impacts on Equipment}

Coal injection into a blast furnace has several impacts on furnace performance. One effect is to alter the temperature profile in the furnace. The coal being injected through the tuyeres is much colder than the coke which has descended through the furnace and been heated by the ascending hot gases. Therefore, injecting coal lowers the temperature at the tuyere zone. Coal injection increased refractory temperatures and thermal load on both Furnaces $\mathrm{C}$ and D. However, because of the increased cooling capacity installed on Furnace $\mathrm{C}$ during the last reline, $\mathrm{C}$ was better able to handle the increased thermal load than D. Although the coal injection rate on Furnace $\mathrm{C}$ approached $300 \mathrm{lb} / \mathrm{NTHM}$, the coal injection rate on Furnace D was restricted to about 240 lb/NTHM.

Another effect is to increase the sulfur and ash load on the furnace, due to the higher sulfur and ash content of the coal compared to coke and, especially, natural gas, which is sulfur and ash free. Coal injection also results in lowered furnace permeability. If permeability becomes too low, movement of the burden through the furnace will not be satisfactory. With natural gas, permeability is about 1.70, whereas, with coal injection at 240-260 lb/NTHM, permeability is $1.20-1.25$.

Although the above effects require the operators to make some adjustments to furnace operations, these changes are relatively minor, and completely satisfactory operation of the furnace with granular coal injection was achieved. Furnace permeability with coal injection is improved by slightly increasing the oxygen enrichment of the air, which decreases the total volume of air required, and adding moisture (steam) to the air. Some of the steam reacts to produce hydrogen, which seems to help maintain proper burden movement through the furnace. The added ash and sulfur can be handled by changing the chemistry of the slag, which is charged to the furnace by varying the quantity and composition of the material.

The refractory wear monitor readings from the beginning of the $\mathrm{C}$ furnace campaign indicated that brick wear increased as coal injection rates increased. However, it is not clear that this increased wear was due to coal injection. The refractory wear patterns of previous furnace campaigns at Burns Harbor show that after twenty months of service with coal injection, there is less refractory wear on $\mathrm{C}$ furnace than during the three previous furnace campaigns without coal injection. However, the previous campaigns did not have the high-density cooling configuration that was installed on the $\mathrm{C}$ furnace before coal injection commenced.

A number of problems were encountered during startup of the BFGCI system, the most serious of which was caused by water condensation on the inside walls of the prepared coal silos. This caused coal to cake on the walls and eventually to block the injectors. The problem was solved by insulating the coal silos [Beth. Steel, April 1996, April 1997]. Also, the cyclones had to be replaced due to erosion. 


\section{Technical and Environmental Assessment}

This section provides an assessment of the technical and environmental performance of the project.

\section{IV.A. Technical Results}

The first eight months of operation with coal injection on both furnaces was with high volatile Sydney bituminous coal. During the following seven months, six different low volatile coals were injected. Data on most of these coals are shown in Table 1. The data generated during this period were examined to determine a satisfactory base period for use in comparing other operations. It was decided to use the low volatile coal period of October 1996 for this purpose. During this period, furnace operations were stable, and the injection facilities supplied coal for the entire period without interruption. The coal injection rate varied from 246 to $278 \mathrm{lb} / \mathrm{NTHM}$, with the average being $264 \mathrm{lb} / \mathrm{NTHM}$. Coke usage during this period averaged $661 \mathrm{lb} / \mathrm{NTHM}$.

Table 1

Analyses of Coals Injected At Burns Harbor

\begin{tabular}{|c|c|c|c|c|c|c|c|}
\hline Coal & $\begin{array}{c}\text { Sydney } \\
\text { (Kentucky) }\end{array}$ & $\begin{array}{c}\text { Virginia } \\
\text { Pocahontas }\end{array}$ & Buchanan & $\begin{array}{l}\text { Falcon } \\
\text { Energy }\end{array}$ & $\begin{array}{c}\text { Maple } \\
\text { Meadow }\end{array}$ & $\begin{array}{c}\text { Buchanan } \\
\text { (High Ash) }\end{array}$ & $\begin{array}{c}\text { Oxbow } \\
\text { (Colorado) }\end{array}$ \\
\hline $\begin{array}{l}\text { Volatile } \\
\text { Matter, \% }\end{array}$ & 36.00 & 18.00 & 19.55 & 16.50 & 18.40 & 18.75 & 37.14 \\
\hline Moisture, \% & 3.0 & 1.5 & 1.5 & 1.5 & 1.4 & $6.46^{*}$ & $5.91 *$ \\
\hline \multicolumn{8}{|c|}{ Ultimate Analysis, wt\% } \\
\hline Carbon & 77.82 & 86.80 & 86.95 & 85.93 & 85.08 & 84.21 & 73.20 \\
\hline Hydrogen & 5.39 & 4.39 & 4.20 & 4.20 & 3.99 & 3.87 & 5.11 \\
\hline Nitrogen & 1.50 & 1.12 & 1.21 & 1.30 & 1.50 & 1.12 & 1.72 \\
\hline Sulfur & 0.63 & 0.80 & 0.75 & 0.58 & 0.77 & 0.75 & 0.76 \\
\hline Chlorine & 0.20 & 0.20 & 0.22 & 0.05 & 0.11 & 0.12 & 0.02 \\
\hline Oxygen & 6.98 & 1.40 & 1.52 & 2.20 & 3.06 & 2.24 & 7.99 \\
\hline Ash & 7.48 & 5.29 & 5.15 & 5.74 & 5.49 & 7.69 & 11.20 \\
\hline HHV, Btu/lb & 13,900 & 14,900 & 15,029 & 14,550 & 14,775 & 14,425 & 13,208 \\
\hline HGI & 46 & 100 & 101 & 94 & 90 & & 47 \\
\hline
\end{tabular}

* As received 


\section{IV.A.1. Granular Coal Injection versus Natural Gas Injection}

Table 2 compares operations injecting granular coal with operations injecting natural gas.

Table 2

\section{Comparisons of Coal Injection with Natural Gas Injection}

\begin{tabular}{|c|c|c|}
\hline Supplemental Fuel & Natural Gas & Buchanan Coal \\
\hline Particle Size & & Granular \\
\hline Production Rate, NTHM/day & 7436 & 6943 \\
\hline $\begin{array}{l}\text { Fuel Rate } \\
\text { Coke, lb/NTHM } \\
\text { Natural Gas, lb/NTHM } \\
\text { Injected Coal, lb/NTHM }\end{array}$ & $\begin{array}{c}740 \\
141 \\
0\end{array}$ & $\begin{array}{c}661 \\
0 \\
264\end{array}$ \\
\hline $\begin{array}{l}\text { Burden } \\
\text { Sinter, wt } \% \\
\text { Pellets, wt } \% \\
\text { Miscellaneous, wt } \% \\
\text { BOF Slag, lb/NTHM }\end{array}$ & $\begin{array}{c}32.3 \\
67.0 \\
0.7 \\
0\end{array}$ & $\begin{array}{c}35.9 \\
63.8 \\
0.3 \\
5\end{array}$ \\
\hline $\begin{array}{l}\text { Blast Conditions } \\
\text { Dry Air, SCFM } \\
\text { Blast Pressure, psig } \\
\text { Permeability } \\
\text { Oxygen in Wind, \% } \\
\text { Temperature, F } \\
\text { Moisture, grains/SCF } \\
\text { Flame Temperature, F } \\
\text { Top Temperature, F } \\
\text { Top Pressure, psig }\end{array}$ & $\begin{array}{c}167,381 \\
38.9 \\
1.57 \\
24.4 \\
2,067 \\
3.7 \\
3,620 \\
263 \\
16.1\end{array}$ & $\begin{array}{c}137,005 \\
38.8 \\
1.19 \\
27.3 \\
2,067 \\
19.8 \\
3,841 \\
226 \\
16.9\end{array}$ \\
\hline $\begin{array}{l}\text { Coke } \\
\text { Water Content, wt } \%\end{array}$ & 4.8 & 5.0 \\
\hline $\begin{array}{l}\text { Hot Metal } \\
\text { Silicon, wt } \% \\
\text { Sulfur, wt } \% \\
\text { Phosphorous, wt } \% \\
\text { Manganese, wt } \% \\
\text { Temperature, F }\end{array}$ & $\begin{array}{c}0.44 \\
0.043 \\
0.070 \\
0.40 \\
2,745\end{array}$ & $\begin{array}{c}0.50 \\
0.040 \\
0.072 \\
0.43 \\
2,734\end{array}$ \\
\hline $\begin{array}{l}\text { Slag } \\
\mathrm{SiO}_{2} \text {, wt } \% \\
\mathrm{Al}_{2} \mathrm{O}_{3}, \mathrm{wt} \% \\
\mathrm{CaO}, \mathrm{wt} \% \\
\mathrm{MgO}, \mathrm{wt} \% \\
\mathrm{Mn}, \mathrm{wt} \% \\
\text { Sulfur, wt } \% \\
\text { Volume, lb/NTHM }\end{array}$ & $\begin{array}{c}38.02 \\
8.82 \\
37.28 \\
12.02 \\
0.45 \\
0.85 \\
394\end{array}$ & $\begin{array}{c}36.54 \\
9.63 \\
39.03 \\
11.62 \\
0.46 \\
1.39 \\
424\end{array}$ \\
\hline
\end{tabular}

The most significant difference in operations was a decrease in wind volume (air rate) with coal injection, which resulted from oxygen enrichment being increased from $24.4 \%$ to $27.3 \%$. 
Moisture addition in the form of steam was increased from 3.7 grains/SCF of blast to 19 grains/SCF. These changes in wind volume, oxygen enrichment, and moisture level were necessary to achieve satisfactory permeability and burden movement.

Furnace slag chemistry also changed, with sulfur content increasing from $0.85 \%$ with natural gas injection to $1.39 \%$ with coal injection. Slag volume was increased by increasing the amount of limestone in the burden to handle the additional sulfur. Blast furnace slag chemistry and volume are determining factors in the final sulfur content in the hot metal, which must meet specifications set by the processes that convert the raw iron to finished steel.

Although operating conditions had to be altered somewhat, operation with injected granular coal was quite satisfactory and presented no major problems. The quantity of blast furnace coke that is replaced by an injected fuel is an important aspect of the overall value of the injectant. The replacement ratio for a blast furnace injected fuel is defined as the amount of furnace coke that is replaced by one pound of the injectant, after accounting for coke requirement changes caused by variables other than the injected fuel. For the Burns Harbor operation, 25 months of operating data were used in a regression analysis to determine the replacement ratio of granulated coal injection. The results are shown in Figure 5, where the adjusted furnace coke rate is plotted against the injected coal rate.

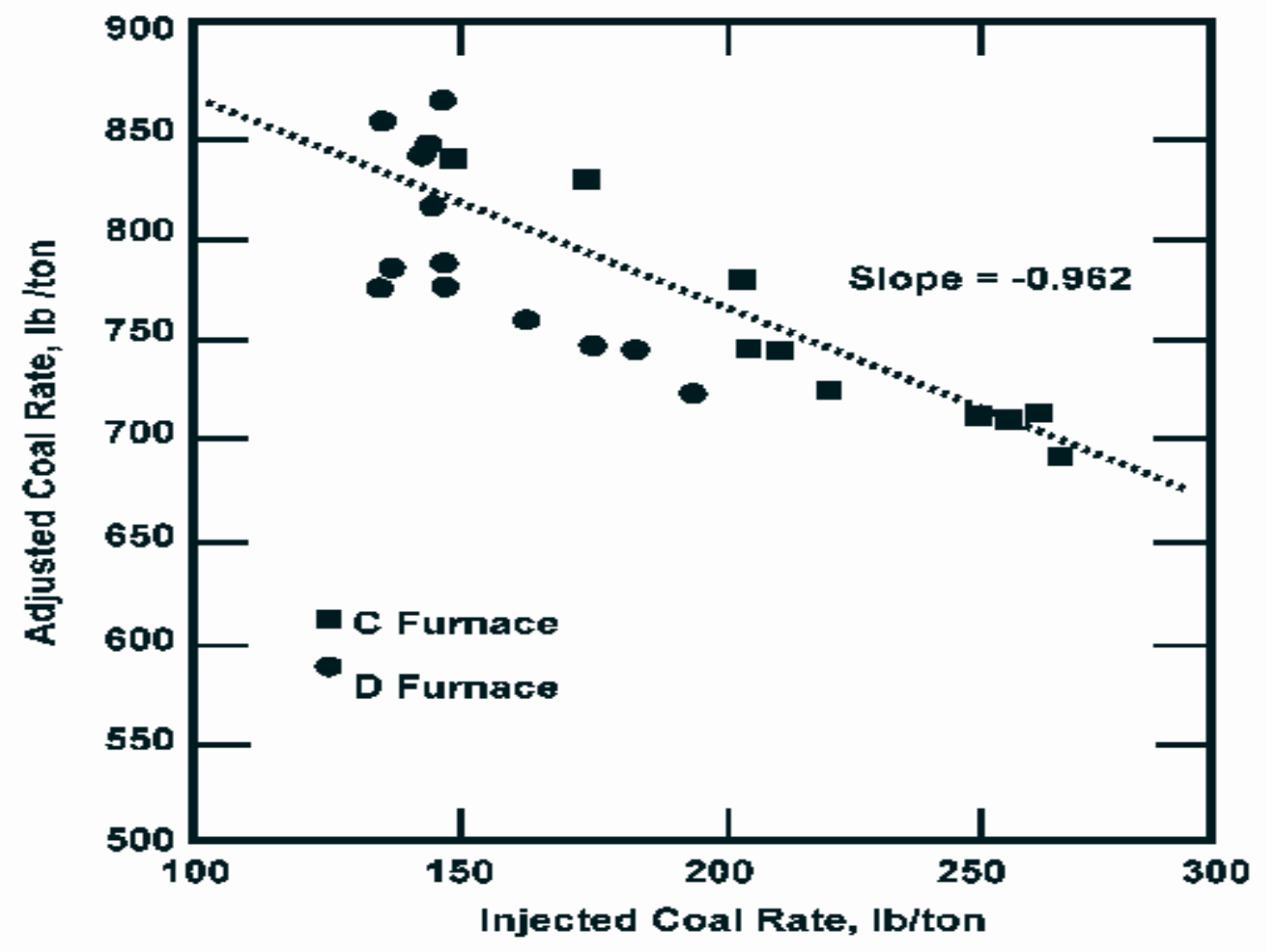

Figure 5: Regression Analysis-Injection Coal vs. Adjusted Coke Rate

The slope of the best fit line is 0.96 , that is, 0.96 fewer pounds of coke are required for each pound of granular coal injected. This is an excellent replacement rate, significantly better than the 0.8-0.9 replacement ratio reported for other coal injection projects. 


\section{IV.A.2. High Ash Versus Low Ash Coal}

During 1996, the coal injected into both Furnaces C and D was low volatile, low ash bituminous coal from either the Buchanan or Virginia Pocahontas mines. Both mines produce coal from the same seam, and the chemical analyses of the coals are very similar. To eliminate coal composition as a variable in this test, one of the steps in the coal cleaning process used at the Buchanan mine was skipped which increased the ash content of the coal by 2.4-3.0\% without significantly changing the analysis on an ash free basis.

Operations with the higher ash coal were compared with similar periods injecting lower ash coal (see Table 3). The operating periods being compared had similar wind rates, blast pressure, top pressure, oxygen enrichment, and moisture addition. The major conclusions from this test were: (1) furnace permeability was not adversely affected by the higher ash coal; (2) blast pressure and wind volume could be maintained at the same conditions as for low ash coal; and (3) hot metal silicon and sulfur contents and variability were comparable to operations with low ash coal. Also, thermal load values and calculated heat loss were virtually unchanged. However, as expected, slag volume increased 3-8\% compared to low ash coal operations.

Table 3

Comparison of High and Low Ash Coals

\begin{tabular}{|l|c|c|}
\hline \multicolumn{1}{|c|}{ Coal } & Buchanan & Buchanan (High Ash) \\
\hline Particle Size & Granular & Granular \\
\hline Production Rate, NTHM/day & 7,207 & 7,437 \\
\hline Fuel Rate & & \\
Coke, lb/NTHM & 673 & 674 \\
Natural gas, lb/NTHM & 0 & 5 \\
Injected Coal, lb/NTHM & 269 & 262 \\
\hline Burden & & \\
Sinter, wt\% & 27.0 & 34.9 \\
Pellets, wt\% & 72.8 & 64.9 \\
Miscellaneous, wt\% & 0.2 & 0.2 \\
BOF Slag, lb/NTHM & 53 & 0 \\
& & \\
\hline Blast Conditions & & \\
Dry Air, SCFM & 135,683 & 135,370 \\
Blast Pressure, psig & 38.2 & 38.3 \\
Permeability & 1.25 & 1.23 \\
Oxygen in Wind, \% & 28.5 & 28.6 \\
Temperature, F & 2,046 & 2,012 \\
Moisture, grains/SCF & 20.4 & 20.7 \\
Flame Temperature, F & 4,002 & 3,953 \\
Top Temperature, F & 195 & 199 \\
Top Pressure, psig & 17.0 & 16.6 \\
\hline
\end{tabular}


Table 3, continued

\begin{tabular}{|l|c|c|}
\hline \multicolumn{1}{|c|}{ Coal } & Buchanan & Buchanan (High Ash) \\
\hline Coke & & \\
Water Content, wt\% & 4.9 & 5.0 \\
\hline Hot Metal & & \\
Silicon, wt\% & 0.51 & 0.49 \\
Sulfur, wt\% & 0.040 & 0.035 \\
Phosphorous, wt\% & 0.069 & 0.073 \\
Manganese, wt\% & 0.42 & 0.46 \\
Temperature, F & 2,741 & 2,733 \\
\hline Slag & & \\
$\mathrm{SiO}{ }_{2}, w t \%$ & 36.08 & 36.21 \\
$\mathrm{Al} 2$ O, wt\% & 9.43 & 9.91 \\
$\mathrm{CaO}, \mathrm{wt} \%$ & 38.86 & 39.40 \\
MgO, wt\% & 12.03 & 11.32 \\
Mn, wt\% & 0.42 & 0.45 \\
Sulphur, wt\% & 1.45 & 1.40 \\
Volume, lb/NTHM & 448 & 461 \\
\hline Corrected Coke Rate, lb/NTHM & 673 & 682 \\
\hline
\end{tabular}

A comparison of coke requirements for operations with the high and low ash coals showed that, at the same coal injection rate, that is, the same pounds of coal per NTHM, for each $1 \%$ increase in coal ash content there is about a $3 \mathrm{lb} / \mathrm{NTHM}$ increase in the coke requirement. This increased coke requirement is consistent with the decreased carbon content of the injected coal. During the test periods, the coal injection rate was about $260 \mathrm{lb} / \mathrm{NTHM}$. The difference in carbon content of the high ash and low ash coals is about $3 \%$, so that, at the same coal injection rate, there are about $260 \times 0.03=7.8$ fewer pounds of carbon in the high ash coal. This value is close to the increased coke requirement.

\section{IV.A.3. Effect of Coal Type}

The objective of this test was to determine the effect of coal type on furnace operations; specifically, a comparison was made between low volatile Eastern bituminous coal (Buchanan) and high volatile Western bituminous coal (Oxbow). Although furnace operation was satisfactory with the Oxbow coal from Colorado, the coke rate was higher than for operation with low volatile bituminous coal (see Table 4). Part of this difference can be attributed to the lower carbon content of the Oxbow coal. However, this does not account for all the difference; the rest is due to the higher ash content of the Oxbow coal, which results in a larger slag volume. Increased slag volume requires a higher coke rate. 


\section{IV.A.4. Granular Coal versus Pulverized Coal}

The objective of this test was to determine whether there is an operating advantage for reducing the particle size of the coal being injected into the blast furnace. The coal used for this study was the high volatile Oxbow coal. The pulverized coal injection rate was somewhat lower than that for granular coal because of the limited capacity of the grinding mills to produce pulverized coal.

Comparison of furnace performance for the two cases of injecting pulverized coal and injecting granular coal shows very similar results (see Table 4). This indicates that there is no advantage to further reducing particle size below the granular range. In fact, there is an economic disadvantage associated with pulverized coal. First, capital costs are higher because either more or larger mills are required to provide pulverized coal; and, second, more power is required to operate the mills. Grinding the Oxbow coal to granular size required $19.6 \mathrm{kWh} /$ ton, whereas pulverizing the coal required $31.4 \mathrm{kWh} / \mathrm{ton}$, an increase of $60 \%$.

Table 4

Comparison of High and Low Volatile Coals

\begin{tabular}{|l|c|c|c|}
\hline \multicolumn{1}{|c|}{ Coal } & Buchanan & Oxbow & Oxbow \\
\hline Particle Size & Granular & Granular & Pulverized \\
\hline Production Rate, NTHM/day & 7,078 & 6,689 & 6,710 \\
\hline Fuel Rate & & & \\
Coke, lb/NTHM & 683 & 798 & 800 \\
Natural gas, lb/NTHM & 2 & 2 & 0 \\
Injected Coal, lb/NTHM/day & 250 & 190 & 183 \\
\hline Burden & & & \\
Sinter, wt\% & 30.8 & 35.3 & 35.7 \\
Pellets, wt\% & 69.0 & 64.6 & 63.6 \\
Miscellaneous, wt\% & 0.2 & 0.1 & 0.7 \\
BOF Slag, lb/NTHM & 10 & 0 & \\
\hline Blast Conditions & & & 141,539 \\
Dry Air, SCFM & 149,599 & 150,096 & 37.4 \\
Blast pressure, psig & 37.6 & 38.0 & 1.33 \\
Permeability & 1.43 & 1.42 & 26.4 \\
Oxygen in Wind, \% & 25.5 & 25.3 & 2,080 \\
Temperature, F & 2,089 & 2,044 & 22.8 \\
Moisture, grains/SCF & 21.1 & 19.3 & 3,935 \\
Flame Temperature, F & 3,836 & 3,870 & 197 \\
Top Temperature, F & 263 & 216 & 16.6 \\
Top Pressure, psig & 16.7 & 17.0 & \\
\hline
\end{tabular}


Table 4, continued

\begin{tabular}{|l|c|c|c|}
\hline \multicolumn{1}{|c|}{ Coal } & Buchanan & Oxbow & Oxbow \\
\hline Coke & & & \\
Water Content, wt\% & 4.7 & 5.1 & 5.2 \\
Chinese Coke, \% & 14.5 & 12.3 & 0.0 \\
\hline Hot Metal & & & \\
Silicon, wt\% & 0.49 & 0.60 & 0.52 \\
Sulfur, wt\% & 0.041 & 0.036 & 0.035 \\
Phosphorous, wt\% & 0.058 & 0.062 & 0.061 \\
Manganese, wt\% & 0.37 & 0.40 & 0.39 \\
Temperature, F & 2,652 & 2,640 & 2,686 \\
\hline Slag & & & \\
$\mathrm{SiO}_{2}, w t \%$ & 37.30 & 36.60 & 36.20 \\
$\mathrm{Al} \mathrm{O}_{3}, \mathrm{wt} \%$ & 9.47 & 10.46 & 10.50 \\
$\mathrm{CaO}, \mathrm{wt} \%$ & 40.09 & 39.29 & 38.82 \\
$\mathrm{Mn}, \mathrm{wt} \%$ & 11.21 & 11.26 & 0.72 \\
$\mathrm{Sulfur}, \mathrm{wt} \%$ & 0.36 & 0.37 & 1.33 \\
Volume, lb/NTHM & 1.45 & 1.43 & 504 \\
\hline Corrected Coke Rate, lb/NTHM & 430 & 461 & 726 \\
\hline
\end{tabular}

\section{IV.B. Environmental Performance}

The BFGCI facility was designed to comply with all applicable federal and Indiana Department of Environmental Management (IDEM) air, water, and solid waste environmental regulations. The operation of the full-scale demonstration project did not have any measurable effect on the volumes or compositions of any plant emissions. Since the startup of the facility in 1995, and after four years of operation, there are no issues of environmental performance or compliance.

\section{IV.B.1. BFGCI Facility Air Emissions}

The CAAA of 1990 regulate emissions of a number of pollutants of concern in steelmaking, primarily certain hazardous air pollutants (HAPs) as well as $\mathrm{SO}_{2}, \mathrm{NOx}$, and particulates. Air pollutants associated with steelmaking emanate primarily from two different sources: directly from steelmaking operations and indirectly from coke oven batteries employed to supply coke for blast furnaces. Air emissions from cokemaking operations pose a much more serious problem than those from steelmaking.

For blast furnace operations, the major issue is control of particulate matter (PM). PM emissions for blast furnaces are, in general, based on opacity limits (typically $20 \%$ opacity for varying frequencies and durations). The Burns Harbor blast furnaces operated within specified limits during the course of this project. Blast furnace gas monitoring for sulfur during each of the trials 
with coal injection was also conducted. The monitoring showed no increase in the sulfur content of the gas.

Coal fugitive dust emissions with a size less than 10 microns $\left(\mathrm{PM}_{10}\right)$ are also regulated by IDEM. Achieving these limits was accomplished by installing control devices in the coal handling, coal preparation, and coal injection areas and by applying a dust suppressant to appropriate coal conveying transfer points.

\section{IV.B.2. BFGCI Facility Wastewater Compliance}

There were no adverse effects on wastewater streams during operation of the facility. All wastewater monitoring results since the startup of the coal injection were within applicable IDEM limitations.

\section{IV.B.3. CAAA Standards Applied to Cokemaking}

A much more serious pollution control problem occurs in cokemaking. Cokemaking is one of the steel industry's areas of greatest environmental concern, with potential air emissions and quench wastewater as major pollutant contributors. Therefore, pressure on coke batteries is being intensified through increasingly stringent environmental requirements from the Environmental Protection Agency's rulemaking. As environmental regulations become stricter, it will become increasingly difficult and more costly to operate coke oven batteries.

In response to these more stringent regulatory constraints and the aging of U.S. coke plants, U.S. steel makers are turning to new technologies to decrease pollution from, and reliance on, cokemaking. Pollution prevention has focused on two areas: reducing coke oven emissions and developing ironmaking techniques that minimize or eliminate coke requirements.

Standard by-product coke ovens emit a variety of pollutants from different locations in the cokemaking process. In a typical battery, there may be leaks from doors, lids, and offtake pipes. These emissions are basically raw coke oven gas (COG), which is rendered visible by the condensation of vapors. These vapors include coal tar, pitch, and creosote, and typically contain methane, ammonia, hydrogen cyanide, hydrogen sulfide, carbonyl sulfide, and various hydrocarbons such as benzene, toluene, and xylene. Additional emissions occur when the coal is fed into the oven at the beginning of a new coking cycle. Since ambient temperature coal is dropped into ovens that are about $2000{ }^{\circ} \mathrm{F}$, some of the same materials that exist in COG may be emitted during charging operations. However, the major emissions during charging are particulates, mainly coal dust.

Emissions also occur at the end of a coking cycle when the coke is pushed from the oven into a car and quenched with water. During normal pushing operations, when coke oven doors are opened, emissions consist primarily of $\mathrm{PM}$ as well as $\mathrm{CO}$ and $\mathrm{CO}_{2}$ from oxidation of the hot coke upon contact with air. The hot coke is quickly quenched with a large volume of water. The rapid 
evolution of steam releases particulate matter to the environment. In addition, any pollutants in the quench water can become airborne either as gas/vapor or as fine particulates. If a push occurs before the coal is completely coked (green coke), enormous quantities of COG, particulates, and combustion products can enter the atmosphere.

Typically, cleaned COG is burned to provide the heat for the coking process and the combustion products exit the oven through the battery stack, thereby offering the potential for emissions of $\mathrm{NO}_{\mathrm{X}}, \mathrm{SO}_{2}$, and PM.

The major environmental concern is that COG contains a number of known carcinogens. Epidemiological studies of coke oven workers have reported an increase in cancer of the lungs, trachea, bronchus, kidney, bladder, prostate, and other sites. EPA has classified coke oven emissions as a Group A, human carcinogen. In addition to their carcinogenic properties, coke oven emissions can cause conjunctivitis, severe dermatitis, and lesions of the respiratory and digestive systems. In addition to the threat to health, coke oven emissions cause degradation of the environment, as would any source of particulate matter and odorous gases.

The CAAA set specific standards for HAPs that can be emitted from coke ovens. EPA issued Maximum Achievable Control Technology (MACT) standards and Lowest Achievable Emission Rate (LAER) standards on December 4, 1992. Emission standards promulgated for coke ovens under the CAAA are increasingly more stringent over time, with individual batteries being affected on dates determined by selected regulatory compliance tracts. On November 15, 1993, coke producers had to select between two major compliance tracts, each setting different numerical standards and compliance dates for limiting cokemaking emissions. All batteries, regardless of the option selected, will have to meet a residual-risk standard that is based on minimizing the risk to public health and surrounding communities. These standards have not yet been promulgated.

The coke ovens at Bethlehem's Burns Harbor facility had to comply with numerical standards that took effect on November 15, 1993 and applied until January 1, 1998. Since that date, the batteries have had to meet more stringent standards consistent with LAER until January 1, 2010, when standards will tighten again. Full compliance with the residual-risk standard must occur in 2020 .

To reduce emissions, Burns Harbor completed a pad-up rebuild in 1994 of the No. 2 coke battery, thereby significantly reducing pollutant emissions. The company installed new door systems on 204 ovens. Maintenance of the batteries will extend their life and help to achieve compliance with upcoming environmental regulations. The 284 coke ovens at Burns Harbor will continue to supply coke primarily to the Burns Harbor blast furnaces. The company expects to produce coke while meeting all applicable regulations through at least 2005. To reduce Bethlehem Steel's reliance on coke, the company installed the BFGCI technology on Blast Furnaces C and D [Hogan and Koelble, Dec. 1996].

The EPA headquarter's Office of Enforcement and Compliance Assistance has included the iron and steel industry as a "priority" industrial sector for purposes of Agency enforcement attention 
over the last few years. Multimedia penalties within the iron and steel industry alone have already exceeded \$10 million, and compliance and remediation costs have exceeded \$200 million [Babst and Donofrio, 1999].

As regulatory deadlines approach and enforcement actions increase, more coke plants will be forced to close, and the current deficit in domestic coke supply is likely to widen appreciably. Although the coke industry faces technological and financial difficulties in meeting regulatory standards, the BFGCI project at Burns Harbor will help to diminish the steel industry's reliance on coke and will, therefore, reduce overall pollutant emissions associated with cokemaking.

\section{IV.C. Evaluation of Project Achievements}

This section evaluates the success of this project by comparing actual accomplishments with project objectives. The primary goal of this CCT project was to demonstrate the technical and economic viability of granular coal injection as a fuel supplement on a large blast furnace. This goal has clearly been achieved. Long periods of coal injection into both Blast Furnaces C and D have been sustained, with a coke replacement ratio of nearly one-to-one. This has resulted in considerable cost savings for Bethlehem Steel, since it has eliminated their need for coke and natural gas purchases.

The fact that the initial target of achieving a coal injection level of $400 \mathrm{lb} / \mathrm{NTHM}$ was not reached is disappointing, but is not significant in judging the success of this project. The Public Design Report says the equipment was designed to inject coal at a rate "up to $400 \mathrm{lb} / \mathrm{NTHM}$." Thus, the $400 \mathrm{lb}$ figure was a target and not a specific goal that had to be attained; the actual maximum achieved of $295 \mathrm{lb} / \mathrm{NTHM}$ is a significant fraction of this target. Furthermore, the limitation on coal injection rate is site specific to the Burns Harbor facility. The compressors that supply wind to the blast furnaces have limited capacity and cannot supply the required air at the increased pressure drop encountered at high coal injection rates. Other facilities without limited compressor capacity are able to achieve coal injection rates of $400 \mathrm{lb} / \mathrm{NTHM}$.

The results relative to specific goals are discussed in the following paragraphs.

\section{IV.C.1. Design, Construct, and Operate BFGCI Demonstration Plant}

The demonstration facility was successfully designed, constructed, and operated. Although some problems were encountered, they were relatively minor and were successfully overcome. As indicated above, sustained periods of operation have been achieved which produced iron at production levels and quality equivalent to that achieved prior to granular coal injection. 


\section{IV.C.2. Evaluate a Range of Coal Types and Particle Sizes}

The effect of coal grind size and coal type on blast furnace performance was established by the various tests discussed in Section IV.A. These tests showed that both pulverized and granular coal can be used on a large blast furnace with good results. Essentially identical results were obtained when injecting the same coal ground to granular and pulverized sizes. Thus, there is no operational advantage to pulverizing the coal, while there is an economic disadvantage. Furthermore, attempts to inject pulverized low volatile coal were unsuccessful for operating reasons.

Significantly better results were obtained using low volatile coal compared to injecting high volatile coal. Thus, although it appears that almost any coal could be used, these results point to using a relatively low ash, low volatile bituminous coal ground to the granular size range for best operation.

\section{IV.C.3. Demonstrate Installation Without Prolonged Shutdown}

The BFGCI technology was successfully installed on both Blast Furnaces C and D without a serious disruption of operations. Because of the nature of the technology, most of the equipment can be installed without impacting operation of the blast furnace. The only equipment installation that requires a blast furnace shutdown is placing the coal injection lances in the tuyeres. Thus, the BFGCI process is well suited to installation without a significant interruption of operations.

\section{IV.C.4. Demonstrate Scaleup of the BFGCI Technology}

The BFGCI technology was successfully installed and operated on both Blast Furnaces C and D. This clearly demonstrates that the process can be scaled up to at least the 7000 NTHM/day range.

\section{IV.C.5. Demonstrate Operation at Full Production Levels While Maintaining Hot Metal Quality}

As discussed in Section IV.A, injection of coal had some impact on furnace operations, such as increasing slag volume and decreasing permeability. However, by changing slag chemistry, increasing oxygen enrichment, and adding steam to the hot blast, satisfactory operation was achieved with no significant effect on hot metal quality.

\section{IV.C.6. Determine Blast Furnace Production Rate as a Function of the Feed Rates of the Various Furnace Inputs}

Extensive data to meet this objective were gathered during the tests discussed in Section IV.A. These data are listed in the Final Report [Beth. Steel, Oct. 1999] and are not reproduced here. 


\section{IV.C.7. Demonstrate Feasibility of Injecting Lower Quality Coal}

Two types of lower quality coal were injected: higher ash coal and Western coal. Both types of lower quality coal were successfully injected, although coke replacement rates were lower because of the higher ash and lower carbon contents. Thus, although this project clearly demonstrated the feasibility of injecting lower quality coal, there are advantages to high quality coal, particularly low ash, low volatile bituminous coals with a high grindability index.

\section{IV.C.8. Characterize the Environmental Aspects of the BFGCI Demonstration}

The BFGCI technology itself has negligible impact on the environment. There is some water runoff from the coal pile, which is handled along with runoff from other coal piles. The only other potential environmental problem is dust from grinding equipment, but particulates are removed from all gas streams before they are emitted to the atmosphere. The compositions of the process streams from the blast furnace were found not to be significantly impacted by granular coal injection.

\section{IV.C.9. Characterize the Process and By-product Streams from the Demonstration}

The only process stream produced by the demonstrated technology is the granulated coal stream injected into the blast furnace. The important characteristics of this stream are its flow rate, composition, and particle size distribution. All of these characteristics have been thoroughly determined, and their values are included in the various reports listed in the bibliography. There are no significant by-product streams from the technology. Occasionally, material must be removed from the grinding mills, where tramp iron or other foreign materials can accumulate and cause problems. After removal, this material is sent to waste disposal.

Coal injection has a minor effect on the three process streams coming from the blast furnace: hot metal, slag, and blast furnace gas. The effect on these streams is also documented in the reports referred to above. These streams are not process streams from the demonstration, since all of these streams existed before the demonstration was carried out.

\section{IV.C.10. Provide Operating and Maintenance Data Suitable to Allow Technical and Economic Evaluation of the BFGCI Technology}

The discussion of operations and economics in other sections of this report shows that this objective was satisfactorily achieved. Each test period is well documented by information presented in reports on the individual trials [Beth. Steel, Trial 1 Nov. 1997, Trial 2 Nov. 1997, April 1999]. 


\section{Market Analysis}

\section{V.A. Potential Market}

Table 5 lists the blast furnaces currently operating in the United States. Thirty-five blast furnaces are currently operating in the U. S. Of these, 17 already use some form of coal injection and may not be immediate candidates for the BFGCI process; however, because of the economic advantages of granular coal injection and the relative ease of handling granulated coal, there could be incentive for furnaces now injecting pulverized coal to switch to granulated coal. For the other 18 blast furnaces, most of which are injecting natural gas, the economic advantages of granular coal injection makes them candidates for installation of the BFGCI technology.

Table 5

List of Blast Furnaces in the U. S.

\begin{tabular}{|c|c|c|}
\hline Company & Plant Location & $\begin{array}{c}\text { Furnace } \\
\text { Designation }\end{array}$ \\
\hline Acme Steel Company & Chicago, IL & A \\
\hline AK Steel Corporation & $\begin{array}{l}\text { Ashland, KY } \\
\text { Middletown, OH }\end{array}$ & $\begin{array}{c}\text { Amanda } \\
\# 3\end{array}$ \\
\hline Bethlehem Steel Corporation & $\begin{array}{l}\text { Burns Harbor, IN } \\
\text { Sparrows Point, MD }\end{array}$ & $\begin{array}{c}\mathrm{C}, \mathrm{D} \\
\mathrm{L}\end{array}$ \\
\hline Geneva Steel & Vineyard, UT & $\# 1$ \\
\hline Gulf States & Gadsden, AL & $\# 2$ \\
\hline Inland, Ispat Steel Company & Chicago, IL & $\# 5, \# 6, \# 7$ \\
\hline LTV Steel Corporation & $\begin{array}{l}\text { Cleveland, OH } \\
\text { East Chicago, IN }\end{array}$ & $\begin{array}{l}\mathrm{C} 1, \mathrm{C} 5, \mathrm{C} 6 \\
\mathrm{H} 3, \mathrm{H} 4\end{array}$ \\
\hline National Steel Corporation & $\begin{array}{l}\text { Ecorse, MI } \\
\text { Granite City, IL }\end{array}$ & $\begin{array}{c}\mathrm{A} 1, \mathrm{~B} 2, \mathrm{D} 4 \\
\mathrm{~A} 1, \mathrm{~B} 2\end{array}$ \\
\hline Rouge Steel Company & Dearborn, MI & $\mathrm{B}, \mathrm{C}$ \\
\hline U. S. Steel Group & $\begin{array}{l}\text { Braddock, PA } \\
\text { Fairfield, AL } \\
\text { Gary, IN }\end{array}$ & $\begin{array}{c}\# 1, \# 3 \\
\# 8 \\
\# 4, \# 6, \# 8, \# 13\end{array}$ \\
\hline USS/Kobe & Lorain, $\mathrm{OH}$ & \#3, \#4 \\
\hline Weirton Steel Corporation & Weirton, WV & $\# 1$ \\
\hline Wheeling-Pittsburgh Steel Corp. & Steubenville, $\mathrm{OH}$ & $\# 1, \# 5$ \\
\hline
\end{tabular}

Source: Iron and Steelmaker, August 1999 


\section{V.B. Economic Assessment}

Because costs tend to be very site specific, it is difficult to project costs that are generally applicable to a wide number of blast furnaces. Among the factors which affect economics are: site location, coke production capacity at the site, coal costs at the site, nature of the alternative fuel being injected into the blast furnace, alternative fuel cost, availability of land near the blast furnace, and labor costs. The following section will review the economics of the BFGCI process at the Burns Harbor facility and then comment on what the economics might look like for other blast furnaces.

\section{V.B.1. Capital Costs}

The installed capital cost for the equipment needed to operate the BFGCI technology on one blast furnace at Burns Harbor was \$15.1 million in 1990, broken down as follows (numbers are millions of dollars):

\begin{tabular}{lr} 
Coal Delivery and Handling & 0.4 \\
Coal Preparation & 8.5 \\
Grinding Mill & 1.8 \\
Conveyer to Injection Building & 0.2 \\
Injection Equipment & 3.8 \\
Conveyor to Blast Furnace \& Injection & 0.4 \\
\multicolumn{1}{c}{ Total } & 15.1
\end{tabular}

These are the costs for one injection facility. At Burns Harbor, two units were installed, one for Furnace $\mathrm{C}$ and one for Furnace D. The $\$ 15.1$ million figure does not include the cost of site preparation, buildings, utilities, and other infrastructure modifications. At Burns Harbor, these facilities required an additional $\$ 87$ million. Thus, the total installed equipment cost of $\$ 30$ million (total for both units) must be multiplied by a factor of 3 to 4 to cover the entire cost of $\$ 117$ million. Infrastructure costs are quite site specific and can vary widely from location to location. Each of these facilities has the capability to inject up to 1440 tons of granular coal per day. On this basis, capital costs are in the neighborhood of $\$ 35,000$ to $\$ 40,000$ per daily ton of injected coal. Because of the need to test both granular and pulverized coal, the capital cost of the grinding mill at Burns Harbor was higher than it would be for a unit designed to inject only granular coal. 


\section{V.B.2. Operating Costs}

As with capital costs, operating costs are also highly site specific. In particular, they will depend upon coal cost, labor rates, and utility costs. At Burns Harbor in June 1999, operating costs (excluding capital charges) were about $\$ 10 /$ ton of injected coal, broken down as follows:

\begin{tabular}{ll} 
Labor & $\$ 1.82$ \\
Maintenance & $\$ 4.43$ \\
Utilities & $\$ 3.56$ \\
\multicolumn{1}{c}{ Total } & $\$ 9.81$
\end{tabular}

To this must be added the cost of coal, which runs $\$ 50-60 /$ ton for the low volatile coal delivered to Burns Harbor from Virginia. Thus, total operating costs are in the range of \$60-70/ton of injected coal, not including capital charges.

\section{V.B.3. Economic Analysis}

The following analysis is based on comparison of a stabilized period of very successful operation injecting granular low volatility coal with typical operations before installation of the BFGCI system, when natural gas injection was used. During the base period, coke consumption was 740 $\mathrm{lb} / \mathrm{NTHM}$ and natural gas consumption was $140 \mathrm{lb} / \mathrm{NTHM}$. After installation of BFGCI, natural gas injection was replaced by injection of $264 \mathrm{lb}$ of granular coal per NTHM. This resulted in a decrease in coke usage to $661 \mathrm{lb} / \mathrm{NTHM}$. Thus, coke usage decreased by $79 \mathrm{lb} / \mathrm{NTHM}$, natural gas usage decreased by $140 \mathrm{lb} / \mathrm{NTHM}$, and coal usage increased by $264 \mathrm{lb} / \mathrm{NTHM}$. Using a purchased coke price of $\$ 130 /$ ton $(6.5 \notin / \mathrm{lb})$, a natural gas price of $\$ 2.88 /$ million Btu $(6.6 \notin / \mathrm{lb}$ at $1000 \mathrm{Btu} / \mathrm{SCF})$, and an injected coal price of $\$ 60 /$ ton $(3.0 \phi / \mathrm{lb})$, the net effect of the above changes in fuel usage is a savings of $\$ 6.50 /$ NTHM.

At Burns Harbor each of the two blast furnaces averages about 7000 NTHM/day, for a yearly production rate of 5.11 million tons. The total capital investment for the BFGCI system, including cost of equipment and infrastructure improvements, was $\$ 117$ million. Savings are 5.11 million tons times $\$ 6.50 /$ ton or $\$ 34.9$ million per year. Dividing $\$ 117$ million by this value gives a payout period of 3.4 years. This is an attractive payout period and shows that the BFGCI technology can significantly improve the economics of blast furnace operation.

\section{V.B.4. Comparison with Other Technologies}

Because of lack of information and variations in costs from site to site, it is difficult to compare the economics of the BFGCI system with other blast furnace coal injection technologies. In general, information on other technologies is not available due to the proprietary nature of the data required for a satisfactory comparison. However, a few general comments are possible. Because of the reasonably short payout period, the BFGCI system should compare favorably with other coal injection technologies. In particular, since BFGCI uses granular coal versus pulverized 
coal used by some other systems, the savings in grinding costs should lead to superior economics for the BFGCI technology. Both capital and operating costs for grinding are reduced capital costs because cheaper equipment is required to produce granular coal compared to pulverized coal and operating costs because of longer mill life and reduced power requirements with granular coal.

\section{V.C. Commercialization of the Technology}

The primary responsibility for commercialization of the BFGCI technology lies with ATSI, Inc., the subcontractor for the granular equipment for the demonstration project. The granular coal injection technology consists of the engineering knowledge and experience to successfully design and manufacture the coal injection system for a specific customer. The hardware itself consists of assemblies of commercially available subsystems. Additional manufacturing capacity or capabilities are not required to satisfy the projected market demand.

Bethlehem Steel's responsibility has included making the demonstration project available for observation, providing operating and engineering personnel for discussion with potential customers, providing test data on the coals and process variables tested, and participation in the preparation and presentation of technical papers pertaining to the demonstration program. Successful completion of the demonstration project provides an important marketing factor in promoting granular coal injection. For example, the blast furnace tour of the Burns Harbor facilities that occurred during the Spring 1999 International Iron and Steel Conference enabled many domestic and foreign blast furnace operators to observe the successful operation of granular coal injection. 


\section{Conclusions}

The BFGCI Demonstration Project was highly successful. The required equipment was designed, installed, and started up with a minimum of problems. The technology performed as expected, and a series of tests was successfully carried out. The economics have proven to be quite favorable, and Bethlehem Steel is continuing to use the BFGCI system on a commercial basis. Environmentally, this technology reduces emissions from coke production by decreasing blast furnace coke requirements on essentially a pound for pound basis; that is, for every pound of coal injected one less pound of coke is required.

Specific conclusions derived from this demonstration project are:

- Granular coal injection on a large blast furnace is technically sound and economically viable. Coal can replace coke on an almost pound for pound basis. The short payout period makes the BFGCI technology very attractive economically.

- There is no need to pulverize the coal, since granular coal performs as well as pulverized coal.

- There is a significant economic advantage to using granular coal over pulverized coal, since not only is less grinding equipment required with consequent capital cost savings, but operating costs are also reduced as approximately $60 \%$ less grinding energy is required for granular coal.

- Although both high volatile and low volatile coals can be injected, blast furnace operation with granular low volatile coal is superior to operation with granular high volatile coal. A pound of low volatile coal replaces more coke than a pound of high volatile coal.

- With certain coals, such as low volatile coal, it is necessary to use granular sizing, because line plugging and other problems arise when trying to inject these pulverized coals.

- Although higher ash coals can be successfully injected, at an injection rate of $260 \mathrm{lb} / \mathrm{NTHM}$, there is a coke rate disadvantage of about $3 \mathrm{lb} / \mathrm{NTHM}$ for each percent increase in the ash content of the injected coal. However, the higher ash content has no adverse effect on furnace permeability, productivity, or hot metal quality. 


\section{Abbreviations}

$\begin{array}{ll}\text { BFGCI } & \begin{array}{l}\text { Blast Furnace Granulated Coal Injection (System) } \\ \text { basic oxygen furnace }\end{array} \\ \text { BOF } & \text { Clean Air Act Amendment (of 1990) } \\ \text { CCT } & \text { Clean Coal Technology Program } \\ \text { CO } & \text { carbon monoxide } \\ \text { COG } & \text { coke oven gas } \\ \text { DOE } & \text { (U.S.) Department of Energy } \\ \text { EPA } & \text { Environmental Protection Agency } \\ \text { H/C } & \text { hydrogen to carbon ratio } \\ \mathrm{H}_{2} & \text { hydrogen } \\ \text { HAPs } & \text { hazardous air pollutants } \\ \text { IDEM } & \text { Indiana Department of Environment Management } \\ \text { kW } & \text { kilowatt } \\ \text { LAER } & \text { lowest achievable emission rate } \\ \text { MACT } & \text { Maximum Achievable Control Technology } \\ \mathrm{MWe}_{\mathrm{NO}} & \text { megawatt electric } \\ \mathrm{NTHM}_{\mathrm{X}} & \text { nitrogen oxides } \\ \text { PM } & \text { net tons of hot metal } \\ \mathrm{SO}_{2} & \text { particulate matter } \\ & \text { sulfur dioxide }\end{array}$




\section{References}

Babst III, C. R. and C. G. Donofrio. Winter 1999. "Legal News: Iron and Steel Multimedia Enforcement in the Next Millenium." Pittsburgh Engineer Magazine.

Bethlehem Steel Corporation. April 1996. Blast Furnace Granular Coal Injection ProjectAnnual Report January-December 1995.

Bethlehem Steel Corporation. April 1997. Blast Furnace Granular Coal Injection ProjectAnnual Report January-December 1996.

Bethlehem Steel Corporation. November 1997. Blast Furnace Granular Coal Injection-Results with Low Volatile Coal. Clean Coal III Project: Blast Furnace Granular Coal Injection Project-Trial 1 Report.

Bethlehem Steel Corporation. November 1997. Blast Furnace Granular Coal Injection—Results with Higher Ash Coal. Clean Coal III Project: Blast Furnace Granular Coal Injection Project-Trial 2 Report.

Bethlehem Steel Corporation. April 1999. Blast Furnace Granular Coal Injection Results Using Pulverized and Granulated High Volatile Coal—Report on Trials 3 and 4.

Bethlehem Steel Corporation. October 1999. Project Performance and Economics. Blast Furnace Granular Coal Injection System Demonstration Project-Final Report Volume 2.

Hogan, W. T. and F. T. Koelble. December 1996. Steel's Coke Deficit: 5.6 million Tons and Growing. New Steel. 


\section{Bibliography}

Babst III, C. R. and C. G. Donofrio. Winter 1999. "Legal News: Iron and Steel Multimedia Enforcement in the Next Millenium." Pittsburgh Engineer Magazine.

Bethlehem Steel Corporation. June 1994. Blast Furnace Granular Coal Injection ProjectAnnual Report December 1993.

Bethlehem Steel Corporation. March 1995. Blast Furnace Granular Coal Injection System Demonstration Project Public Design Report.

Bethlehem Steel Corporation. July 1995. Blast Furnace Granular Coal Injection Project-Annual Report January-December 1994.

Bethlehem Steel Corporation. April 1996. Blast Furnace Granular Coal Injection ProjectAnnual Report January-December 1995.

Bethlehem Steel Corporation. April 1997. Blast Furnace Granular Coal Injection ProjectAnnual Report January-December 1996.

Bethlehem Steel Corporation. November 1997. Blast Furnace Granular Coal Injection-Results with Low Volatile Coal. Clean Coal III Project: Blast Furnace Granular Coal Injection Project-Trial 1 Report.

Bethlehem Steel Corporation. November 1997. Blast Furnace Granular Coal Injection—Results with Higher Ash Coal. Clean Coal III Project: Blast Furnace Granular Coal Injection Project-Trial 2 Report.

Bethlehem Steel Corporation. April 1998. Blast Furnace Granular Coal Injection ProjectAnnual Report January-December 1997.

Bethlehem Steel Corporation. April 1999. Blast Furnace Granular Coal Injection ProjectAnnual Report January-December 1998.

Bethlehem Steel Corporation. April 1999. Blast Furnace Granular Coal Injection Results Using Pulverized and Granulated High Volatile Coal—Report on Trials 3 and 4.

Bethlehem Steel Corporation. October 1999. Project Performance and Economics. Blast Furnace Granular Coal Injection System Demonstration Project_Final Report Volume 2.

Gathergood, D. S. April 26, 1988. Coal Injection into the Blast Furnace. International Iron \& Steel Institute Committee on Technology.

Gathergood, D. S. and G. Cooper. 1988. Blast Furnace Injection-Why Granular Coal? Steel Technology International. 
Hill, D. G., T. J. Strayer, and R. W. Bouman. April 1998. Blast Furnace Granular Coal Injection System Demonstration Project. Sixth Clean Coal Technology Conference, Reno, NV.

Hill, D. G., T. J. Strayer, and R. W. Bouman. January 1997. An Update on Blast Furnace Granular Coal Injection. Fifth Annual Clean Coal Technology Conference, Tampa, FL.

Hogan, W. T. and F. T. Koelble. November 1996. Fewer Blast Furnaces, But Higher Productivity. New Steel.

Hogan, W. T. and F. T. Koelble. December 1996. Steel's Coke Deficit: 5.6 million Tons and Growing. New Steel.

Kwasnoski, D. and L. L. Walter. September 1993. Blast Furnace Granular Coal Injection. Second Annual Clean Coal Technology Conference, Atlanta, GA.

Kwasnoski, D. and L. L. Walter. September 1994. Blast Furnace Granular Coal Injection. Third Annual Clean Coal Technology Conference, Chicago, IL.

U. S. Department of Energy. October 1990. Comprehensive Report to Congress Clean Coal Technology Program-Blast Furnace Granulated Coal Injection System Demonstration Project.

U.S. Department of Energy. November 1999. "Blast Furnace Granular Coal Injection System Demonstration Project." Clean Coal Technology Topical Report Number 15.

Walter, L. L., R. W. Bouman, and D. G. Hill. September 1995. Blast Furnace Granular Coal Injection. Fourth Annual Clean Coal Technology Conference, Denver, CO. 